\title{
PROGRAMS IN RENEWABLE ENERGY
}

DOE/CE/ 10093--71

Rewist:

DE89 009486

APR 231990

\section{Geothermal Energy \\ Program Summary}

Volume II:

Research Summaries

Fiscal Year 1989

\section{U.S. Department of Energy}

Prepared by the

Solar Technical Information Program

Solar Energy Research Institute

Golden, CO $80401-3393$

DOE/CH10093-71

DE89009486

January 1990

U.C. Category: 250 


\section{DISCLAIMER}

This report was prepared as an account of work sponsored by an agency of the United States Government. Neither the United States Government nor any agency Thereof, nor any of their employees, makes any warranty, express or implied, or assumes any legal liability or responsibility for the accuracy, completeness, or usefulness of any information, apparatus, product, or process disclosed, or represents that its use would not infringe privately owned rights. Reference herein to any specific commercial product, process, or service by trade name, trademark, manufacturer, or otherwise does not necessarily constitute or imply its endorsement, recommendation, or favoring by the United States Government or any agency thereof. The views and opinions of authors expressed herein do not necessarily state or reflect those of the United States Government or any agency thereof. 


\section{DISCLAIMER}

Portions of this document may be illegible in electronic image products. Images are produced from the best available original document. 


\section{Contents}

Introduction $\ldots \ldots \ldots \ldots \ldots \ldots \ldots \ldots \ldots \ldots \ldots \ldots \ldots \ldots \ldots \ldots \ldots$

FY 1989 Contract Descriptions $\ldots \ldots \ldots \ldots \ldots \ldots \ldots \ldots \ldots \ldots \ldots \ldots \ldots \ldots$

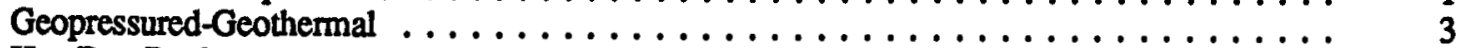

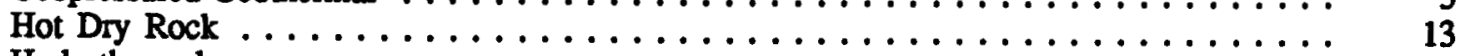

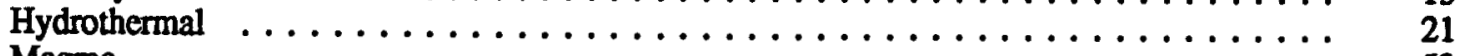

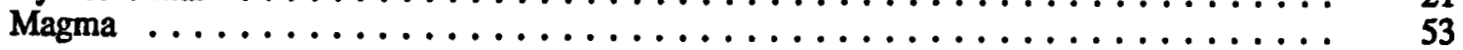

Current Publications $\ldots \ldots \ldots \ldots \ldots \ldots \ldots \ldots \ldots \ldots \ldots \ldots \ldots \ldots \ldots \ldots \ldots \ldots \ldots$

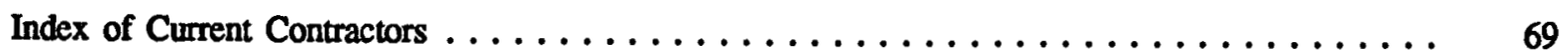





\section{Introduction}

The Geothermal Technology Division (GTD) of the U.S. Department of Energy (DOE) is charged with the lead federal role in the research and development (R\&D) of technologies that will assist industry in economically exploiting the nation's vast geothermal resources. The GTD R\&D Program represents a comprehensive, balanced approach to establishing all forms of geothermal energy as significant contributors to the nation's energy supply. It is structured both to maintain momentum in the growth of the existing hydrothermal industry and to develop long-term options offering the greatest promise for practical applications.

The Geothermal Energy Program Summary for Fiscal Year 1989 is a two-volume set. It is designed to be an easily accessible reference to inform the U.S. geothermal industry and other interested parties of the technological advances and progress achieved in the DOE Geothermal Program, as well as to describe the thrust of the current R\&D effort and future R\&D directions.

Volume I (Publication No. DOE/CH10093-70) contains technical descriptions of the four categories of geothermal resources addressed by the program, the status of the technologies attendant to their development, a brief history of the program, an overview of the projects under way, and the accomplishments achieved in FY 1989. It also describes the management framework of the program and sets forth the FY 1989 budget.

This volume, Volume II, contains a detailed compilation of each GTD-funded R\&D activity performed by national laboratories or under contract to industrial, academic, and nonprofit research institutions. It is organized in accordance with the GTD R\&D work breakdown structure. The structure hierarchy consists of Resource Category (geopressured-geothermal, hot dry rock, hydrothermal, and magma), Project (reservoir technology, hard rock penetration, etc.), Task (reservoir analysis, lost-circulation control, etc.), and Activity (fracture detection and mapping, scientific drilling, etc.). Major reports cited in each summary are abbreviated; complete citations can be found in the list of current publications at the end of the document. The Program Summary is intended as an important technology transfer vehicle to assure the wide and timely dissemination of information concerning DOE's geothermal research. 


\section{FY 1989 Contract Descriptions}


Geopressured-Geothermal

$3 / 4$ 



\section{Well Production Testing}

Project/Task:

Well Operations/Gladys McCall Reservoir

Directing Organization:

Idaho Operations Office

785 DOE Place

Idaho Falls, ID 83402

Project Manager: K. Taylor

Telephone: 583-9063 (FTS) (208) 526-9063 (Com)

Contractor:

Eaton Operating Company, Inc.

1980 Post Oak Blvd., Suite 2000

Houston, TX 77056

Principal Investigator: B. Eaton

Telephone: (713) 627-9764 (Com)

Contract Number: AC07-85ID12578

Contract Period: 01/10/85 - 09/30/93

Contract Funding (Source):

FY 1989: \$379,000 (DOE)

\section{Objectives:}

To develop techniques by 1992 to increase confidence in the ability to locate and evaluate geopressured resources (these techniques should be of sufficient quality that at least $90 \%$ of wells recompleted for geopressured-geothermal development are subsequently shown to be economic) and to determine the drive mechanisms for the design wells by 1991 .

\section{Approach/Background:}

Gladys McCall well was shut in October 29, 1987, for a long-term pressure buildup test. Continue to monitor buildup of shut-in bottom hole pressure. Use pressure buildup data to modify reservoir simulator if necessary. Develop a standard procedure that operators can use during or immediately after drilling to indicate resource potential.

\begin{abstract}
Status/Accomplishments:
Successful scale inhibitor squeezes at the Gladys McCall well permitted a high volume of production proving the existence of a large reservoir capable of producing for several years. The well also provided unique histories on brine-gas production versus pressure decline, brine chemistry, aromatic hydrocarbons, and environmental data. Pressure buildup tests began when the well was shut in and have been continued through FY 1989.
\end{abstract}

Major Project Reports: None

Summary Date: October 1989 


\section{Well Production Testing}

\author{
Project/Task: \\ Well Operations/Pleasant Bayou Reservoir \\ Directing Organization: \\ Idaho Operations Office \\ 785 DOE Place \\ Idaho Falls, ID 83402 \\ Project Manager: K. Taylor \\ Telephone: 583-9063 (FTS) \\ (208) 526-9063 (Com) \\ Contractor: \\ Eaton Operating Company, Inc. \\ 1980 Post Oak Blvd., Suite 2000 \\ Houston, TX 77056 \\ Principal Investigator: B. Eaton \\ Telephone: (713) 627-9764 (Com) \\ Contract Number: AC07-85ID12578 \\ Contract Period: 01/10/85 - 09/30/93 \\ Contract Funding (Source): \\ FY 1989: $\$ 956,000$ (DOE)
}

\section{Objectives:}

To develop techniques to increase confidence in the ability to locate and evaluate geopressured resources by 1992 (these techniques should be of sufficient quality that at least $90 \%$ of wells recompleted for geopressured-geothermal development are subsequently shown to be economic) and to determine the drive mechanisms for the design wells by 1991 .

\section{Approach/Background:}

Renewed flow testing at Pleasant Bayou began in May 1988 to acquire reservoir drawdown data and eventually supply energy to the hybrid power system. Continue long-term flow tests, and evaluate scale-inhibitor treatment. Use drawdown data to modify reservoir simulator if necessary. Develop a standard procedure that operators can use during or immediately after drilling to indicate resource potential.

\section{Status/Accomplishments:}

The well was placed into production in May 1988. The well continued to flow at an average of 20,000 barrels of brine per day prior to connection with the hybrid power system. Three obstacles at the well were overcome: (1) sanding was controlled by adjustment of the flow rate; (2) calcium carbonate scaling was controlled by a phosphorate inhibitor, and (3) corrosion, largely the result of turbulence, is being addressed by reducing turbulent flow. Modifications were completed to prepare for use with the hybrid power system. Flow rate has been cut to 16,000 barrels per day.

\section{Major Project Reports:}

Eaton, B.A., C.R. Featherston, and T.E. Meahl, "Pleasant Bayou Operations, Brazoria County, Texas."

Summary Date: October 1989 


\section{Well Production Testing}

Project/Task:

Well Operations/Hulin Reservoir

Directing Organization:

Idaho Operations Office

785 DOE Place

Idaho Falls, ID 83402

Project Manager: K. Taylor

Telephone: 583-9063 (FTS)

(208) 526-9063 (Com)

Contractor:

Eaton Operating Company, Inc.

1980 Post Oak Blvd., Suite 2000

Houston, TX 77056

Principal Investigator: B. Eaton

Telephone: (713) 627-9764 (Com)

Contract Number: AC07-85ID12578

Contract Period: 01/10/85 - 09/30/93

Contract Funding (Source):

FY 1989: $\$ 4,474,000$ (DOE)

\section{Objective:}

To develop techniques to increase confidence in the ability to locate and evaluate geopressured resources by 1992 . These techniques should be of sufficient quality that at least $90 \%$ of wells recompleted for geopressured-geothermal development are subsequently shown to be economic.

\section{Approach/Background:}

The Hulin well (originally a gas well) encounters geopressured reservoirs that are the deepest and hottest in the program. Conversion of this well into a geopressured brine production well will yield valuable data about the deep, geopressured resource. Continue workover of the Hulin well and update test plan.

\section{Status/Accomplishments:}

The Hulin well was renovated and 3 1/2-in. tubing was installed. The well was put on standby in anticipation of FY 1990 flow testing. A disposal well was drilled and completed. A test plan for preliminary testing was also developed.

Major Project Reports: None

Summary Date: October 1989 


\section{Geopressured Reservoir Depletion}

Project/Task:

Geoscience and Engineering Support/Liquid

Hydrocarbons

Directing Organization:

Idaho Operations Office

785 DOE Place

Idaho Falls, ID 83402

Project Manager: I. Aoki

Telephone: 583-0583 (FTS)

(208) 526-0583 (Com)

Contractor:

University of Southwestern Louisiana

P.O. Box 44250, USL

Lafayette, LA 70504-4250

Principal Investigator: D.F. Keeley

Telephone: (318) 231-5671 (Com)

Contract Number: DE-AS07-83NV10338

Contract Period: 09/01/83 - 12/31/89

Contract Funding (Source):

FY 1989: $\$ 150,000$ (DOE)

Objective:

To determine source and flow mechanisms for the liquid hydrocarbons and methane being obtained from producing geopressured reservoirs by 1991.

Approach/Background:

Obtain laboratory analyses of hydrocarbon composition. Review the geology of the reservoirs and study adjacent oil or gas wells that might be producing from geopressured zones. Develop conceptual model of hydrocarbon source and flow mechanisms.

\section{Status/Accomplishments:}

Data collection continues on measured solubilities of some aromatic hydrocarbons, aliphatic hydrocarbon production, and sampling and analysis of cryocondensates. Production of aromatic cryocondensates was monitored and related to brine flow. An in-line benzene monitor was designed and fabricated and is being tested at Pleasant Bayou.
A pH probe for harsh conditions has been designed and is in the early stages of fabrication and testing.

Major Project Reports: None

Summary Date: October 1989 


\section{Resistivity Neutron Log Interpretation}

Project/Task:

Geoscience and Engineering Support/Logging

Directing Organization:

Idaho Operations Office

785 DOE Place

Idaho Falls, ID 83402

Project Manager: I. Aoki

Telephone: 583-0583 (FTS)

(208) 526-0583 (Com)

\section{Contractor:}

University of Texas at Austin

C.P.E. 2.502

Austin, TX 78712

Principal Investigator: M. Dorfman

Telephone: (512) 471-1267 (Com)

Contract Number: DE-FC07-85NV10412

Contract Period: 10/01/88 - 09/30/89

Contract Funding (Source):

FY 1989: $\$ 450,000$ (DOE)

\section{Objectives:}

To determine the drive mechanisms for the design well reservoirs by 1991 and to develop techniques to increase confidence in the ability to locate and evaluate geopressured resources by 1992 . These techniques should be of sufficient quality that at least $90 \%$ of the wells recompleted for geopressuredgeothermal development are subsequently shown to be economic.

\section{Approach/Background:}

Study the effect of wettability, rock stress, and shale content on rock resistivity, and determine the effects of trace elements on neutron logs to improve interpretation of logs from geopressured wells. Stress reservoir core samples to determine basic rock properties at in situ conditions for input to reservoir simulator. Develop a hydrogeochemical model for fluids in the vicinity of the Pleasant Bayou geopressured well. Maintain the program information system.

\section{Status/Accomplishments:}

Determined saturation exponent for water-wet glass beads using various water saturations. Designed logging program and completed Elan log analysis for the Hulin well. Measured boron in rock samples, cement, and cement additives. Conducted uniaxial, triaxial, and core pressure compaction tests on Gladys McCall and Pleasant Bayou core samples. Also, initiated tensile testing.

\section{Major Project Reports:}

Dunlap, H., "An Overview of Recent Logging Research at the University of Texas Petroleum Engineering Department."

Dunlap, H., "Boron: Tracking a Trace Element."

Summary Date: October 1989 


\section{Reservoir Data Integration}

Project/Task:

Geoscience and Engineering Support/Reservoir

Engineering

Directing Organization:

Idaho Operations Office

785 DOE Place

Idaho Falls, ID 83402

Project Manager: I. Aoki

Telephone: 583-0583 (FTS)

(208) 526-0583 (Com)

Contractor:

S-Cubed (Subcontractor to University of Texas at Austin)

P.O. Box 1620

La Jolla, CA 92038-1620

Principal Investigator: T.D. Riney

Telephone: (619) 453-0060 (Com)

Contract Number: DE-FC07-85NV10412

Contract Period: 10/01/88 - 9/30/89

Contract Funding Source:

FY 1989: \$140,000 (DOE)

Objectives:

To determine the drive mechanisms for the design well reservoirs by 1991 and to develop by 1992 a test procedure that has sufficient accuracy to predict the capability of any geopressured reservoir to be produced for a period of five times the test period.

Approach/Background:

Analyze pressure data from design wells. Develop models of the design well reservoirs using geology, rock compressibility, and reservoir-pressure data. Model the test results to ascertain the presence of one or more theoretically possible drive mechanisms. Modify simulator so it may more accurately model the actual field data.

\section{Status/Accomplishments:}

Performed parametric simulation to match the total data base for the Pleasant Bayou reservoir. Predicted brine flow rates and associated wellbore pressure drop for the Hulin well. Performed reservoir simulation calculations for the depletion and recovery phases of Gladys McCall.

Major Project Reports: None

Summary Date: October 1989 


\section{Environmental Monitoring and Analysis}

\section{Project/Task:}

Geoscience and Engineering Support/Environmental Effects

\section{Directing Organization:}

Idaho Operations Office

785 DOE Place

Idaho Falls, ID 83402

Project Manager: I. Aoki

Telephone: 583-0583 (FTS) (208) 526-0583 (Com)

\section{Contractor:}

Louisiana State University

Louisiana Geological Survey

P.O. Box G

University Station

Baton Rouge, LA 70893-4107

Principal Investigator: C.G. Groat

Telephone: (504) 388-5320 (Com)

Contract Number: DE-FC07-85NV10425

Contract Period: 12/01/88 - 11/30/89

Contract Funding (Source):

FY 1989: \$550,000 (DOE)

\section{Objective:}

To determine if fluids can be disposed of in an environmentally acceptable manner by 1995.

\section{Approach/Background:}

Monitor and analyze surface subsidence, induced seismicity, and water quality in aquifers above the injection zones and in surface waters. Develop a model for reservoir compression that can verify that no adverse environmental effects will occur from the planned production and disposal methods over a 10-year period of operation.

\section{Status/Accomplishments:}

Conducted continuous monitoring of subsidence, seismicity, and water quality near test wells in Louisiana and Texas.

\section{Major Project Reports:}

John, CJ., D.A. Stevenson, and C. Groat, "Geopressured-Geothermal Resources of the Northern Gulf of Mexico Basin-Geology Test Results and Environmental Monitoring."

Summary Date: October 1989 


\section{Geopressured Energy Conversion}

Project/Task:

Energy Conversion/Pleasant Bayou Hybrid Power System

Directing Organization:

Idaho Operations Office

785 DOE Place

Idaho Falls, ID 83402

Project Manager: K. Taylor

Telephone: 583-9063 (FTS)

(208) 526-9063 (Com)

Contractor:

The Ben Holt Co. (Subcontractor to Eaton

Operating Company, Inc.)

5201 South Lake Avenue

Pasadena, CA 91101

Principal Investigator: R. Campbell

Telephone: (213) 684-2541 (Com)

Contract Number: AC07-85ID12578

Contract Period: 10/15/85 - 10/15/90

Contract Funding (Source):

FY 1989: \$1,632,000 (DOE)

\section{Objective:}

To develop hybrid conversion technology with thermal efficiency at least $20 \%$ greater than that from separate combustion and geothermal power cycles by 1992.

\section{Approach/Background:}

Establish hybrid-power-generation technology for using heat, methane, and hydraulic pressure of geopressured brines. The heat and methane can be used to generate electricity, or the heat can be used separately for direct application or electric power production and the methane sold to a pipeline. Cost-shared utilization will help to establish the technical feasibility of efficient power conversion methods. The hybrid power system at Pleasant Bayou will take advantage of the gas and heat from the Pleasant Bayou well to generate electricity.

\section{Status/Accomplishments:}

The design and construction of the hybrid power system at Pleasant Bayou was completed. Final shakedown and safety concerns were addressed in preparation for startup of the system in early FY 1990. A ribbon-cutting ceremony was held at the Pleasant Bayou site on September 15, 1989.

\section{Major Project Reports:}

Negus-de Wys, J., "Status of the Hybrid Power System and Future Utilization Possibilities of the Geopressured Resource."

Summary Date: October 1989 
Hot Dry Rock 



\section{Phase II Energy Extraction System}

Project/Task:

Fenton Hill Operations/Phase II Energy Extraction System

Directing Organization:

Albuquerque Operations Office

P.O. Box 5400

Albuquerque, NM 87115

Project Manager: G.P. Tennyson

Telephone: 846-3219 (FTS)

(505) 846-3219 (Com)

Contractor:

Los Alamos National Laboratory (UC)

P.O. Box 1663

Los Alamos, NM 87545

Principal Investigator: R. Hendron

Telephone: $843-4318$ (FTS)

(505) $667-4318$ (Com)

Contract Number: W-7405-ENG-36

Contract Period: 10/01/83 - Open

Contract Funding (Source):

FY 1989: \$1,712,000 (DOE)

\section{Objectives:}

To evaluate the large Phase II reservoir at Fenton Hill to determine its drawdown characteristics by 1993; to develop cement formulations that result in low-density, moderate-strength, zero-free-water cements for casings by 1995; and to verify that the environmental consequences of hot dry rock (HDR) development are acceptable by 1997.

\section{Approach/Background:}

Conduct a long-term (one-year) flow test of the Phase II reservoir at Fenton Hill. During the period of thermal drawdown, measure the important parameters of reservoir behavior, geochemical interactions, and fluid loss. Develop testing techniques to determine the effective energy production and longevity of fractured HDR reservoirs.

\section{Status/Accomplishments:}

Procured some long-lead components and continued installation work on the surface system for the Long Term Flow Test (LTFT). Conducted pressurization tests to estimate water flow for the LTFT. Completed cleanout and repair of the EE-1, onemillion-gallon storage pond and initiated procurement and installation of new lining and monitoring system.

\section{Major Project Reports:}

Murphy, H., et al., "Hot Dry Rock Fracture Propagation and Reservoir Characterization."

Schillo, J.C., et al., "Redrilling of Well EE-3 at the Los Alamos National Laboratory HDR Project."

Summary Date: October 1989 


\section{Test-Site Support and Utilities}

Project/Task:

Fenton Hill Operations/Phase II Energy Extraction System

Directing Organization:

Albuquerque Operations Office

P.O. Box 5400

Albuquerque, NM 87115

Project Manager: G.P. Tennyson

Telephone: $846-3219$ (FTS)

(505) 846-3219 (Com)

Contractor:

Los Alamos National Laboratory (UC)

P.O. Box 1663

Los Alamos, NM 87545

Principal Investigator: $\mathbf{R}$. Hendron

Telephone: $843-4318$ (FTS)

(505) $667-4318(\mathrm{Com})$

Contract Number: W-7405-ENG-36

Contract Period: 10/01/83 - Open

Contract Funding (Source):

FY 1989: $\$ 599,000$ (DOE)

Objective:

To verify that the environmental consequences of hot dry rock (HDR) development are acceptable by 1997.

\section{Approach/Background:}

Provide support service to Fenton Hill for the continued operation of the Phase II Energy Extraction System. Services include site electric power, water rights, and site maintenance.

\section{Status/Accomplishments:}

With completion of electric load and operating cost studies, plans are to operate the main circulating pump with diesel engines. Continued permits for experimental water use have been obtained and arrangements have been completed to lease water rights to cover this water use. Coordination of Fenton Hill site activities has continued with U.S. DOE Los Alamos Area Office, U.S. Forest Service, New Mexico State Engineers Office, New Mexico
Bureau of Economic Geology, New Mexico Environmental Improvement Division, and the Los Alamos National Laboratory Health and Safety Division.

Major Project Reports: None

Summary Date: October 1989 


\section{Phase II Ancillary Activities}

Project/Task:

Fenton Hill Operations/Phase II Ancillary

Activities

Directing Organization:

Albuquerque Operations Office

P.O. Box 5400

Albuquerque, NM 87115

Project Manager: G.P. Tennyson

Telephone: $\quad 846-3219$ (FTS)

(505) 846-3219 (Com)

Contractor:

Los Alamos National Laboratory (UC)

P.O. Box 1663

Los Alamos, NM 87545

Principal Investigator: $R$. Hendron

Telephone: $843-4318$ (FTS)

(505) $667-4318$ (Com)

Contract Number: W-7405-ENG-36

Contract Period: 10/01/83 - Open

Contract Funding (Source):

FY 1989: \$284,000 (DOE)

Objectives:

To improve instrumentation and hardware to control, locate, and measure fracture propagation in hot dry rock reservoirs and to determine means to accurately locate the intersections of fractures with the wellbore.

Approach/Background:

Conduct downhole instrumentation tests to measure in-situ stress and locate wellbore fracture intersections.

\section{Status/Accomplishments:}

Continued well-logging activities during reservoir tests. Completed acquisition of water-use permits for the Long Term Flow Test and started testing and development of additional water supply to supply makeup water. Under environmental monitoring, water analysis and seismic monitoring were continued.

\section{Major Project Reports:}

Burns, K.L., Geological Structures from Televiewer Logs of GT-2. Fenton Hill: Part 1, Feature Extraction; Part 2, Rectification; Part 3, Quality Control.

Robinson, B.A., "Fracture Network Modeling of a Hot Dry Rock Geothermal Reservoir."

Summary Date: October 1989 


\section{Tools and Instrumentation}

Project/Task:

Scientific and Engineering Support/Tools and Instrumentation

Directing Organization:

Albuquerque Operations Office

P.O. Box 5400

Albuquerque, NM 87115

Project Manager: G.P. Tennyson

Telephone: $846-3219$ (FTS)

(505) 846-3219 (Com)

Contractor:

Los Alamos National Laboratory (UC)

P.O. Box 1663

Los Alamos, NM 87545

Principal Investigator: R. Hendron

Telephone: $\quad 843-4318$ (FTS) (505) 667-4318 (Com)

Contract Number: W-7405-ENG-36

Contract Period: 10/01/83 - Open

Contract Funding (Source):

FY 1989: $\$ 164,000$ (DOE)

\section{Objectives:}

To improve instrumentation and hardware to control, locate, and measure fracture propagation in hot dry rock reservoirs by 1995 and to establish reservoir mapping techniques to locate drilling targets for production wells by 1995 .

\section{Approach/Background:}

Determine fracture propagation and fluid entry and exit locations in the wellbore. Improve output data on downhole microprocessor electronics and enhance the reliability of the data processor.

\section{Status/Accomplishments:}

Conducted wellbore logging as required in support of reservoir testing including pressure and flow tests to estimate possible water losses in the Long Term Flow Test. Continued calibration and maintenance of downhole instruments, flow-system instrumentation, and data acquisition and recording equipment.

\section{Major Project Reports:}

Dreesen, D.S., et al., "Developing Hot Dry Rock Reservoirs with Inflatable Open Hole Packers."

Jermance, R.L., et al., "Applications of a Downhole Programmable Microprocessor for a Geothermal Borehole Inspection Tool."

Summary Date: October 1989 


\section{Technology Application}

Project/Task:

Scientific and Engineering Support/Tools and

Instrumentation

\section{Directing Organization:}

Albuquerque Operations Office

P.O. Box 5400

Albuquerque, NM 87115

Project Manager: G.P. Tennyson

Telephone: $\quad 846-3219$ (FTS) (505) 846-3219 (Com)

Contractor:

Los Alamos National Laboratory (UC)

P.O. Box 1663

Los Alamos, NM 87545

Principal Investigator: $R$. Hendron

Telephone: $843-4318$ (FTS) (505) $667-4318$ (Com)

Contract Number: W-7405-ENG-36

Contract Period: 10/01/83 - Open

Contract Funding (Source): FY 1989: \$158,000 (DOE)

\section{Objective:}

To promulgate system engineering and resource information, as well as hardware developments, from the Hot Dry Rock (HDR) Program to the energyproducing and other interested industries and to cognizant counterpart government and educational institutions, and reciprocally for application in the HDR Program.

\section{Approach/Background:}

Presentation of programmatic efforts and results will be made at a variety of technical conferences such as Geothermal Resources Council Annual Meeting, Stanford Geothermal Workshop, American Geological Union, Energy Technology Conference and Exhibit, and Program Development Council Meetings.

\section{Status/Accomplishments:}

Continued transfer of tool and equipment information, interfaced with industry on Long Term Flow Test participation, coordinated with technology transfer societies, and prepared articles for technology transfer.

Major Project Reports: None

Summary Date: October 1989 


\section{Reservoir Monitoring and Analyses}

Project/Task:

Scientific and Engineering Support/Reservoir

Engineering

Directing Organization:

Albuquerque Operations Office

P.O. Box 5400

Albuquerque, NM 87115

Project Manager: G.P. Tennyson

Telephone: $846-3219$ (FTS)

(505) 846-3219 (Com)

Contractor:

Los Alamos National Laboratory (UC)

P.O. Box 1663

Los Alamos, NM 87545

Principal Investigator: $R$. Hendron

Telephone: $843-4318$ (FTS)

(505) $667-4318$ (Com)

Contract Number: W-7405-ENG-36

Contract Period: 10/01/83 - Open

Contract Funding (Source):

FY 1989: $\$ 689,000$ (DOE)

Objectives:

To develop technology to monitor changes in reservoir volume and temperature and confirm monitoring data using tracers by 1994 , to complete detailed reservoir analyses and confirm modeling of hydraulic and thermal performance of the Phase II system by 1995 , and to determine means to locate accurately the intersection of fractures with the wellbore by 1997 .

\section{Approach/Background:}

Conduct experiments to assess the amount of energy remaining in the reservoir. Monitor changes in the chemical makeup of the extracted fluids to contribute to analytical models used to estimate reservoir size and life. In parallel, inject reacting tracers into the system to validate the empirical models. Study drilling muds and cement formulations using laboratory and field tests. Improve the analysis of high-temperature acoustic televiewer data.

\section{Status/Accomplishments:}

Conducted a series of sustained pressurization tests to determine water losses as a function of pressure. Completed modeling 2D and 3D thermal/fluid dynamic and mass transfer incorporating nonlinear pressure and temperature dependence in a homogeneous continuum model of a reservoir. Reanalyzed microearthquakes from the massive hydraulic fracturing experiment using improved mapping methods and three-point method and initiated programming efforts toward automation. In chemically reactive tracer work, continued adsorption tests in laboratory and development of techniques for analyzing tracers at expected low concentrations.

\section{Major Project Reports:}

Birdsell, S.A., "Prediction of Thermal Front Breakthrough Due to Fluid Reinjection in Geothermal Reservoirs."

Brown, D.W., "Anomalous Earth Stress Measurements during a Six-Year Sequence of Pumping Tests at Fenton Hill, New Mexico."

Summary Date: October 1989 
Hydrothermal

$21 / 22$ 



\section{Fracture Detection and Mapping}

Project/Task:

Reservoir Technology/Reservoir Analysis

Directing Organization:

Idaho Operations Office

785 DOE Place

Idaho Falls, ID 83402

Project Manager: P.A. Brookshier

Telephone: 583-1403 (FTS)

(208) 526-1403 (Com)

\section{Contractor:}

Lawrence Berkeley Laboratory

Earth Science Division, Bldg. 50E

Berkeley, CA 94720

Principal Investigator: M.J. Lippmann

Telephone: $451-5035$ (FTS)

(415) 486-5035 (Com)

Contract Number: AC03-76SF00098

Contract Period: 10/17/83 - Open

Contract Funding (Source):

FY 1989: $\quad \$ 150,000$ (DOE)

\section{Objectives:}

To decrease uncertainties in forecasting short-term and long-term reservoir changes in fluid pressure and flow rate by $10 \%$ by 1992 , by increasing the accuracy and precision of information required for models of reservoir characteristics and performance, and to reduce the number of wells needed to evaluate a reservoir by $10 \%$ by 1992 .

\section{Approach/Background:}

Develop and test downhole geophysical methods for the detection and mapping of fractures. Develop and verify new computer methods to analyze borehole geophysical data for the location of fractures and permeable zones in geothermal systems. Design, develop, and field test instrumentation for surface-to-borehole, borehole-tosurface, and crosshole seismic and electrical surveys.

\section{Status/Accomplishments:}

Progress was made in developing and demonstrating advanced geophysical concepts and techniques for the detection and mapping of permeable zones in geothermal systems. Methods found successful include inhole and crosshole electromagnetic and P-wave and S-wave seismic techniques. Cooperative work with industry was emphasized.

\section{Major Project Reports:}

Majer, E.L., "GTO-DOE/Industry Cost Shared Research; Microseismic Characterization Monitoring in Geothermal Systems."

Stark, K.L., and E.L. Majer, Seismicity of the Southeastern Geysers.

Zhou, Q., N.E. Goldstein, and A. Becker, "Crosshole Electromagnetic Responses of Multiple Thin Conductors."

Summary Date: October 1989 


\section{Fracture Detection and Mapping}

Project/Task:

Reservoir Technology/Reservoir Analysis

Directing Organization:

Idaho Operations Office

785 DOE Place

Idaho Falls, ID 83402

Project Manager: P.A. Brookshier

Telephone: $\quad 583-1403$ (FTS)

(208) 526-1403 (Com)

Contractor:

University of Utah Research Institute

391 Chipeta Way, Suite C

Salt Lake City, UT 84108

Principal Investigator: P.M. Wright

Telephone: $\quad 588-3439$ (FTS)

(801) 524-3439 (Com)

Contract Number: AC07-85ID12489

Contract Period: 10/25/87 - 06/30/90

Contract Funding (Source):

FY 1989: \$220,000 (DOE)

\section{Objectives:}

To decrease uncertainties in forecasting short-term and long-term reservoir changes in fluid pressure and flow rate by $10 \%$ by 1992 , by increasing the accuracy and precision of information required for models of reservoir characteristics and performance, and to reduce the number of wells needed to evaluate a reservoir by $10 \%$ by 1992 .

\section{Approach/Background:}

Develop and verify computer-based methods to evaluate the use of borehole geophysical techniques for locating fractures and permeable zones in geothermal systems. Design, develop, and field test instrumentation for surface-to-borehole, borehole-tosurface, and borehole-to-borehole resistivity and electromagnetic surveys.

\section{Status/Accomplishments:}

Computer programs for the interpretation of borehole-to-surface and borehole-to-borehole surveys were written using inversion mathematical techniques. Equipment specifications were made and instruments were ordered to obtain data sets in hydrothermal reservoirs to test the technique.

Major Project Reports:

Beasley, C.W., Cross-Borehole Resistivity Inversion-Theory and Application to Monitoring Enhanced Oil Recovery.

Beasley, C.W., and S.H. Ward, "Cross-Borehole Resistivity Inversion."

LaBrecque, D.J., Theoretical Studies of the CrossBorehole and Borehole-to-Surface Resistivity Methods.

LaBrecque, D.J., and S.H. Ward, "Two-Dimensional Inversion of Cross-Borehole Resistivity Data Using Moveable Boundaries."

Ward, S.H., and R.C. West, "The Borehole Transient Electromagnetic Response of a Three-Dimensional Fracture Zone in a Conductive Half-Space."

Wright, P.M., S.H. Ward, C.W. Beasley, D.J. LaBrecque, J.A. Stodt, and H.P. Ross, "Research in Borehole Geophysics."

Summary Date: October 1989 


\section{Identification of Reservoir Processes}

Project/Task:

Reservoir Technology/Reservoir Analysis

Directing Organization:

Idaho Operations Office

785 DOE Place

Idaho Falls, ID 83402

Project Manager: P.A. Brookshier

Telephone: $583-1403$ (FTS) (208) 526-1403 (Com)

Contractor:

Lawrence Berkeley Laboratory

Earth Science Division, Bldg. 50E

Berkeley, CA 94720

Principal Investigator: M.J. Lippmann

Telephone: 451-5035 (FTS)

(415) 486-5035 (Com)

Contract Number: AC03-76SF00098

Contract Period: 10/17/83 - Open

Contract Funding (Source):

FY 1989: \$150,000 (DOE)

\section{Objective:}

By improving reservoir evaluation methods, to decrease uncertainties in forecasting short-term and long-term reservoir changes in fluid temperature, pressure, flow rate, and chemistry by $10 \%$ by 1992 .

\section{Approach/Background:}

Through the use of laboratory and computer models, analyze the physical and chemical processes taking place in geothermal reservoirs. Improve the quality of drill-hole information, increase the available drillhole information, and extend investigations beyond the drill hole using new geophysical techniques and improved well-testing methods.

\section{Status/Accomplishments:}

Numerical and laboratory studies of multiphase flowthrough fractures were carried out to determine relative permeability curves for steam-water mixtures. A review of fundamental processes in geothermal reservoirs and related modeling efforts was completed. Further numerical studies of heat transfer in porous systems at near-critical conditions were made. Effects on noncondensible gases on heat pipes in geothermal reservoirs were analyzed.

\section{Major Project Reports:}

Cox, B.L., and K. Pruess, "Numerical Experiments on Convective Heat Transfer in Water-Saturated Porous Media at Near-Critical Conditions."

McKibbin, R., and K. Pruess, "Some Effects of Noncondensible Gas in Geothermal Reservoirs with Steam-Water Counterflow."

Pruess, K., "Experimental and Theoretical Studies of Multiphase Flow in Rough-Walled Rock Fractures."

Pruess, K., "Modeling of Geothermal Systems: Fundamental Processes, Computer Simulation, and Field Applications."

Pruess, K., and Y.W. Tsang, "On Relative Permeability of Rough-Walled Fractures."

Summary Date: October 1989 


\section{Identification of Reservoir Processes}

Project/Task:

Reservoir Technology/Reservoir Analysis

Directing Organization:

Idaho Operations Office

785 DOE Place

Idaho Falls, ID 83402

Project Manager: P.A. Brookshier

Telephone: 583-1403 (FTS)

(208) 526-1403 (Com)

Contractor:

University of Utah Research Institute

391 Chipeta Way, Suite C

Salt Lake City, UT 84108

Principal Investigator: P.M. Wright

Telephone: $588-3439$ (FTS)

(801) 524-3439 (Com)

Contract Number: AC07-85ID12489

Contract Period: 10/25/87 - 06/30/90

Contract Funding (Source):

FY 1989: $\$ 80,000$ (DOE)

Objective:

By improving reservoir evaluation methods, to decrease uncertainties in forecasting short-term and long-term reservoir changes in fluid temperature, pressure, flow rate, and chemistry by $10 \%$ by 1992 .

Approach/Background:

Identify the processes of geothermal systems through analysis and interpretation of the geology, geophysics, geochemistry, and hydrology of the reservoir. Develop hydrogeochemical models of fracture-dominated fluid flow in geothermal systems. Increase drill-hole information from rock cuttings and extend investigations beyond the drilled hole using new geophysical techniques. Develop more reliable geothermometers.

\section{Status/Accomplishments:}

Data developed from fluid inclusions in vein minerals in geothermal systems were more fully developed. Fluid inclusions can give information on the temperature of formation of the circulating fluids, their salinity, and the carbon dioxide content which can be related to past boiling. Thus, fluidinclusion data bear heavily on evolution of the geothermal system and on identification of upwelling and recharge zones and areas of two-phase (water and steam) fluids in the rocks. All of these quantities are important in siting exploration and production wells.

\section{Major Project Reports:}

Lemieux, M.M., J.N. Moore, E.P. Gonzales, G. Izquierdo, and R.E. Huitron, Chemistry of Los Azufres Reservoir Fluids-Data from Fluid Inclusions.

Moore, J.N., "Fluid Inclusions Systematics of the Coso Geothermal System."

Moore, J.N., M.C. Adams, B.P. Bishop, and P. Hirtz, A Fluid Flow Model of the Coso Geothermal System-Data from Production Fluid and Fluid Inclusions.

Moore, J.N., M.C. Adams, B.P. Bishop, and P. Hirtz, "Geochemistry of the Coso Geothermal System in California."

Moore, J.N., J.B. Hulen, M.M. Lemieux, J.N. Sternfeld, and M.A. Walters, "Petrographic and Fluid Inclusion Evidence for Past Boiling, Brecciation and Associated Hydrothermal Alteration above the NW Geysers Steam Field, CA."

Summary Date: October 1989 


\section{Predictive Modeling of Reservoir Behavior}

Project/Task:

Reservoir Technology/Reservoir Analysis

Directing Organization:

Idaho Operations Office

785 DOE Place

Idaho Falls, ID 83402

Project Manager: P.A. Brookshier

Telephone: 583-1403 (FTS)

(208) 526-1403 (Com)

\section{Contractor:}

Stanford University

Department of Petroleum Engineering

360 Mitchell Bldg.

Stanford, CA 94305

Principal Investigator: $R$. Horne

Telephone: (415) 723-9595 (Com)

Contract Number: AS07-84ID12529

Contract Period: 07/25/84 - 12/31/89

Contract Funding (Source):

FY 1989: $\$ 250,000$ (DOE)

\section{Objectives:}

To decrease uncertainties in forecasting short-term and long-term reservoir changes in fluid pressure and flow rate by $10 \%$ by 1992 , by increasing the accuracy and precision of information required for models of reservoir characteristics and performance, and to reduce uncertainties in predictions of reservoir capacity by $10 \%$ by 1992 .

\section{Approach/Background:}

Investigate the fundamental properties of reservoir behavior. Increase experience in field behavior through long-term field case studies, as joint DOE/industry activities where possible; develop well-testing techniques and facilitate acquisition of high quality data; and verify and validate reservoir models.

\section{Status/Accomplishments:}

FY 1989 developments in well-testing techniques promise to expand the understanding of reservoir behavior. A new task, started this year, aims at examining the influence of gravity drainage in a two-phase, segregated reservoir. The task on the use of boundary-element method in well-test analysis was completed; the work succeeded in developing techniques for the analysis of reservoirs that are complex in shape and that may have sectional heterogeneities. New experimental work on the adsorption of steam onto geothermal rocks was initiated.

\section{Major Project Reports:}

Jalali, Y., A.K. Belani, and K. Fujiwara, "An Interporosity Flow Model for Naturally Fractured Reservoirs."

Johns, R.T., and Y. Jalali, "Comparison of Pressure Transient Response in Intensely and Sparsely Fractured Reservoirs."

Kikani, J., Application of Boundary Element Method to Streamline Generation and Pressure Transient Testing.

Kikani, J., and R.N. Horne, "Application of Boundary Element Method to Reservoir Engineering Problems."

Kikani, J., and R.N. Horne, "Modeling Pressure Transient Behavior of Sectionally Heterogeneous Reservoir by the Boundary Element Method."

Summary Date: October 1989 


\section{Predictive Modeling of Reservoir Behavior}

Project/Task:

Reservoir Technology/Reservoir Analysis

Directing Organization:

Idaho Operations Office

785 DOE Place

Idaho Falls, ID 83402

Project Manager: P.A. Brookshier

Telephone: $583-1403$ (FTS) (208) 526-1403 (Com)

Contractor:

Lawrence Berkeley Laboratory

Earth Science Division, Bldg. 50E

Berkeley, CA 94720

Principal Investigator: M.J. Lippmann

Telephone: $451-5035$ (FTS)

(415) 486-5035 (Com)

Contract Number: AC02-76SF00098

Contract Period: 10/17/83 - Open

Contract Funding (Source):

FY 1989: \$150,000 (DOE)

\section{Objectives:}

To decrease uncertainties in forecasting short-term and long-term reservoir changes in fluid pressure and flow rate by $10 \%$ by 1992 , by increasing the accuracy and precision of information required for models of reservoir characteristics and performance, and to reduce uncertainties in predictions of reservoir capacity by $10 \%$ by 1992 .

\section{Approach/Background:}

Improve numerical, conceptual, and physical models for heat and fluid transport and chemical reactions. Increase experience in field behavior through longterm field case studies, as joint DOE/industry activities where possible; develop well-testing techniques and facilitate acquisition of high quality data; and verify and validate reservoir models.

\section{Status/Accomplishments:}

Improvements were made to existing computer codes for calculating transport of heat, mass, and chemical species in geothermal systems. Simulation studies on several fields were carried out. The inherent soundness of geothermal wellfield behavior predictions based on numerical models was documented.

\section{Major Project Reports:}

Bodvarsson, G.S., "Model Predictions of the Svartsengi Reservoir, Iceland."

Bodvarsson, G.S., K. Pruess, C. Haukwa, and S.B. Ojiambo, "Evaluation of Reservoir Predictions for the Olkaria Geothermal Field, Kenya."

Halfman-Dooley, S.E., M.J. Lippmann, and G.S. Bodvarsson, "Progress Report on LBL's Numerical Modeling Studies on Cerro Prieto."

Pruess, K., "Modeling of Fluid and Heat Flow in Geothermal Reservoirs."

Summary Date: October 1989 


\section{Integrated Model for Exploration}

Project/Task:

Reservoir Technology/Exploration Technology

Directing Organization:

Idaho Operations Office

785 DOE Place

Idaho Falls, ID 83402

Project Manager: P.A. Brookshier

Telephone: 583-1403 (FTS)

(208) 526-1403 (Com)

Contractor:

University of Utah Research Institute

391 Chipeta Way, Suite C

Salt Lake City, UT 84108

Principal Investigator: P.M. Wright

Telephone: $588-3439$ (FTS) (801) $524-3439$ (Com)

Contract Number: AC07-85ID12489

Contract Period: 10/25/87 - 06/30/90

Contract Funding (Source):

FY 1989: $\quad \$ 80,000$ (DOE)

Objectives:

To devise better methods and strategies for discovering hidden (blind) hydrothermal systems and exploring the deep extensions of known systems and to provide sufficient technical support so that industry can locate three such hidden reservoirs by 1992.

\section{Approach/Background:}

Apply hydrogeochemical models to exploration and develop models with data acquired through cooperative DOE-industry drilling of deep heat flow holes. Use results of rock property studies to define characteristics of geothermal targets in volcanic terrains. Conduct geothermal exploration in St. Lucia and Mexico to test models.

\section{Status/Accomplishments:}

Analysis methods for borehole breakout data derived from geophysical well logs were developed for geothermal exploration. Breakout data yield information on the in-situ state of stress in the reservoir and on the most likely directions for open fractures. This information is important in exploration and production drilling. In addition, the use of satellite imagery data for reconnaissance exploration of geothermal systems was demonstrated at the Los Azufres field in Mexico.

\section{Major Project Reports:}

Allison M.L., and D.L. Nielson, Variations of InSitu Stress in Geothermal Systems of the Basin and Range Province.

Little, T.M., J.B. Hulen, and D.L. Nielson, "Implications of an Unusual Intracaldera Clastic Deposit for Creation of Fracture Permeability in the Valles Hydrothermal System, New Mexico."

Moore, J.N., D.L. Nielson, and P.M. Wright, Recent Developments in Geology, Geochemistry, and Geophysics Applied to Hydrothermal Reservoir Mapping and Monitoring.

Wright, P.M., E. Lira, and D.R. Ramsey, Interpretation of Landsat Thematic Mapper Satellite Imagery at Los Azufres Geothermal Field, Michoacan, Mexico.

Summary Date: October 1989 


\section{Geophysical Methods to Characterize Reservoirs}

Project/Task:

Reservoir Technology/Exploration Technology

Directing Organization:

Idaho Operations Office

785 DOE Place

Idaho Falls, ID 83402

Project Manager: P.A. Brookshier

Telephone: 583-1403 (FTS)

(208) 526-1403 (Com)

Contractor:

Lawrence Berkeley Laboratory

Earth Science Division, Bldg. 50E

Berkeley, CA 94720

Principal Investigator: M.J. Lippmann

Telephone: $451-5035$ (FTS)

(415) 486-5035 (Com)

Contract Number: AC03-76SF00098

Contract Period: 10/17/83 - Open

Contract Funding (Source):

FY 1989: $\$ 50,000$ (DOE)

\section{Objective:}

To increase the success ratio of wildcat wells, especially in frontier areas such as the Cascades, by $20 \%$ by 1992 .

Approach/Background:

Develop and test new geophysical equipment and data interpretation methods to characterize and develop conceptual models of geothermal systems.

\section{Status/Accomplishments:}

Interpreted repetitive self-potential survey data from two producing geothermal fields: East Mesa, California, and Cerro Prieto, Mexico. While nongeothermal source effects seemed to dominate the East Mesa data, a strong correlation between self-potential and production data was observed at the Cerro Prieto field. Electrochemical potentials caused by fault-controlled leakage of hot fluids in the caprock were suspected in the East Mesa system.

\section{Major Project Reports:}

Goldstein, N.E., and R.J. Alvarez, "Self-Potential Anomaly Changes at the Cerro Prieto Geothermal Field."

Goldstein, N.E., S.E. Halfman, R.F. Corwin, and R.J. Alvarez, "Self-Potential Anomaly Changes at the East Mesa and Cerro Prieto Geothermal Fields."

Summary Date: October 1989 


\section{Geophysical Methods to Locate Reservoirs}

Project/Task:

Reservoir Technology/Exploration Technology

Directing Organization:

Idaho Operations Office

785 DOE Place

Idaho Falls, ID 83402

Project Manager: P.A. Brookshier

Telephone: 583-1403 (FTS)

(208) 526-1403 (Com)

\section{Contractor:}

University of Utah Research Institute

391 Chipeta Way, Suite C

Salt Lake City, UT 84108

Principal Investigator: P.M. Wright

Telephone: 588-3439 (FTS)

(801) 524-3439 (Com)

Contract Number: AC07-85ID12489

Contract Period: 10/25/84 - 06/30/90

Contract Funding (Source):

FY 1989: $\$ 100,000$ (DOE)

\section{Objective:}

To increase the success ratio of wildcat exploration wells, especially in frontier areas such as the Cascades, by $20 \%$ by 1992.

\section{Approach/Background:}

Through geophysical surveys and interpretations of active and fossil hydrothermal systems, develop a better understanding of geophysical anomalies that correlate with active hydrothermal resources and define their locations. Use advanced models of geothermal systems to develop new exploration methods, techniques, and strategies.

\section{Status/Accomplishments:}

Several geophysical methods were studied. Induced polarization (IP) as a junction of frequency was measured for cores of various alteration grades for the purpose of determining if extent and temperature of alteration could be predicted from the IP response. This technique does not appear to be viable. The magnetotelluric response of the Long Valley area, however, seems to indicate a conductive zone under the West Moat area that could be due to a hydrothermal system. An aeromagnetic survey of the Los Azufres area in Mexico showed that this method is valuable for locating previously unknown faults in volcanic terrain, and it is expected that aeromagnetic data would be useful for exploration in the Cascades of the United States.

\section{Major Project Reports:}

Ross, H.P., et al., Aeromagnetic Studies, Los Azufres Geothermal Area, Michoacan.

Tripp, A.C., M.M. Lemieux, P.M. Wright, J.N. Moore, and H.P. Ross, "Physical and Chemical Rock Property Measurements in Geothermal Exploration and Reservoir Studies."

Wannamaker, P.E., "Magnetotellurics in Deep Geothermal Exploration-Applications to the Long Valley Magnetic System."

Summary Date: October 1989 


\section{Tracer Development and Interpretation}

Project/Task:

Reservoir Technology/Brine Injection Technology

Directing Organization:

Idaho Operations Office

785 DOE Place

Idaho Falls, ID 83402

Project Manager: P.A. Brookshier

Telephone: 583-1403 (FTS)

(208) 526-1403 (Com)

Contractor:

Stanford University

Department of Petroleum Engineering

360 Mitchell Bldg.

Stanford, CA 94305

Principal Investigator: R. Horne

Telephone: (415) 723-9595 (Com)

Contract Number: AS07-84ID12529

Contract Period: 07/25/84 - 12/31/89

Contract Funding (Source):

FY 1989: \$115,000 (DOE)

Objective:

To improve reservoir monitoring methods to decrease uncertainties in forecasting short-term and long-term reservoir changes in fluid temperature, pressure, flow rate, and chemistry by $10 \%$ by 1992 .

\section{Approach/Background:}

Develop low-cost tracers for liquid- and gas-phase flow and develop new techniques for tracer injection, sampling, and interpretation as applied to the determination of the physical properties of the reservoir and fluid interactions. Develop methods to predict and track chemical and thermal fronts and determine parameters needed for modeling.

\section{Status/Accomplishments:}

Testing continued on the effectiveness of the reinjection optimization algorithm developed in previous years. The method is being applied to field data from Palinpinon field in the Philippines. Stanford personnel cooperated in a multilab field tracer test at Dixie Valley, Nevada. The work on mass and thermal transport in well-to-well, recirculating, and injection-backflow tracer tests was completed.

Major Project Reports:

Horne, R.N., "Reinjection into Fractured Geothermal Systems."

Kocabas, I., Analysis of Tracer and Thermal Transients During Reinjection.

Summary Date: October 1989 


\section{Tracer Development and Interpretation}

Project/Task:

Reservoir Technology/Brine Injection Technology

Directing Organization:

Idaho Operations Office

785 DOE Place

Idaho Falls, ID 83402

Project Manager: P.A. Brookshier

Telephone: 583-1403 (FTS)

(208) 526-1403 (Com)

\section{Contractor:}

University of Utah Research Institute

391 Chipeta Way, Suite C

Salt Lake City, UT 84108

Principal Investigator: P.M. Wright

Telephone: 588-3439 (FTS)

(808) 524-3439 (Com)

Contract Number: AC07-85ID12489

Contract Period: 10/25/87 - 06/30/90

Contract Funding (Source):

FY 1989: $\$ 180,000$ (DOE)

\section{Objective:}

To improve reservoir monitoring methods to decrease uncertainties in forecasting short-term and long-term reservoir changes in fluid temperature, pressure, flow rate, and chemistry by $10 \%$ by 1992.

\section{Approach/Background:}

Develop low-cost tracers for liquid- and gas-phase flow and develop new techniques for tracer injection, sampling, and interpretation as applied to the determination of the physical properties of the reservoir and fluid interactions. Develop methods to predict and track chemical and thermal fronts and determine parameters needed for modeling.

Status/Accomplishments:

A field test of new organic chemical tracers was conducted in conjunction with Oxbow Geothermal Corporation at Dixie Valley, Nevada. Three injection wells were tagged with a unique suite of tracers, and four production wells were monitored for about two months. Breakthrough of tracer was found after about 10 days in one injectionproduction well pair, but no breakthrough between other wells was detected. Testing of gas-phase tracers was begun in autoclaves for the purpose of determining thermal stability. Gas tracers would be valuable in vapor-dominated reservoirs such as The Geysers.

\section{Major Project Reports:}

Adams, M.C., and J. Davis, Thermal Decay Kinetics of the Tracer Dye Fluorescein.

Adams, M.C., W.R. Benoit, C. Doughty, G.S. Bodvarsson, and J.N. Moore, "The Dixie Valley, Nevada, Tracer Test."

Adams, M.C., J.N. Moore, and P.M. Wright, The Use of Tracers to Analyze the Effects of Reinjection into Fractured Geothermal Reservoirs.

Moore, J.N., M.C. Adams, and L. Fabray, Comparative Study on the Performance of SilicaBased C18 and Polymer Reversed Phases Used for the Analysis of Carboxylic and Sulfonic Acid Geothermal Tracers.

Summary Date: October 1989 


\section{Modeling Injected-Fluid Migration}

Project/Task:

Reservoir Technology/Brine Injection Technology

Directing Organization:

Idaho Operations Office

785 DOE Place

Idaho Falls, ID 83402

Project Manager: P.A. Brookshier

Telephone: 583-1403 (FTS)

(208) 526-1403 (Com)

Contractor:

Stanford University

Department of Petroleum Engineering

360 Mitchell Bldg.

Stanford, CA 94305

Principal Investigator: R. Horne

Telephone: (415) 723-9595 (Com)

Contract Number: AS07-84ID12529

Contract Period: 07/25/84 - 12/31/89

Contract Funding (Source):

FY 1989: \$125,000 DOE

Objectives:

To increase the success ratio of in-fill wells for production and injection, i.e., decrease the dry-hole ratio for in-fill wells for production and injection by $33 \%$ by 1992 ; to improve methods for positioning and designing geothermal production and injection wells to reduce the aggregate cost of wells by $15 \%$ by 1992 ; and to reduce uncertainties related to long-term reservoir changes in fluid temperature and injection breakthrough by $10 \%$ by 1992 .

\section{Approach/Background:}

To predict the effect of injection on production, develop the capability to model behavior of pressure, chemical, and thermal fronts resulting from injected fluids. Identify transport mechanisms governing flow of tracers through fractures.

\section{Status/Accomplishments:}

Analyses were made of field data from Dixie Valley and other fields to identify the transport mechanisms that determine the flow of tracers through fractures. Tracer test results were analyzed to determine fracture orientation and aperture. The research program contributed to the understanding of injection processes through cost-shared projects with industry.

Major Project Reports: None

Summary Date: October 1989 


\section{Modeling Injected-Fluid Migration}

Project/Task:

Reservoir Technology/Brine Injection Technology

Directing Organization:

Idaho Operations Office

785 DOE Place

Idaho Falls, ID 83402

Project Manager: P.A. Brookshier

Telephone: 583-1403 (FTS)

(208) 526-1403 (Com)

\section{Contractor:}

Lawrence Berkeley Laboratory

Earth Science Division, Bldg. 50E

Berkeley, CA 94720

Principal Investigator: M.J. Lippmann

Telephone: $451-5035$ (FTS)

(415) 486-5035 (Com)

Contract Number: AC03-76SF00098

Contract Period: 10/17/83 - Open

Contract Funding (Source):

FY 1989: $\$ 50,000$ (DOE)

\section{Objectives:}

To increase the success ratio of in-fill wells for production and injection, i.e., decrease the dry-hole ratio for in-fill wells for production and injection by $33 \%$ by 1992 ; to improve methods for positioning and designing geothermal production and injection wells to reduce the aggregate cost of wells by $15 \%$ by 1992 ; and to reduce uncertainties related to long-term reservoir changes in fluid temperature and injection breakthrough by $10 \%$ by 1992 .

\section{Approach/Background:}

To predict the effect of injection on production, develop capability to model behavior of pressure, chemical, and thermal fronts resulting from injected fluids. Identify transport mechanisms goveming flow of tracers through fractures.

\section{Status/Accomplishments:}

The theoretical and field aspects of waste brine injection in geothermal reservoirs were reviewed. Further analysis of the permeability enhancement observed during cold water injection in the Los Azufres field was completed. A modeling study of a long-term injection test at Dixie Valley was carried out to study the migration of the injectate and accordingly design the field activities.

\section{Major Project Reports:}

Adams, M.C., W.R. Benoit, C. Doughty, G.S. Bodvarsson, and J.N. Moore, "The Dixie Valley, Nevada, Tracer Test."

Benson, S.M., J.S. Daggett, J. Ortfz, and I. Iglesias, "Permeability Enhancement Due to Cold Water Injection: A Case Study at the Los Azufres Geothermal Field, Mexico."

Bodvarsson, G.S., and V. Stefansson, "Some Theoretical and Field Aspects of Reinjection in Geothermal Reservoirs."

Summary Date: October 1989 


\section{Modeling Injected-Fluid Migration}

Project/Task:

Reservoir Technology/Brine Injection Technology

Directing Organization:

Idaho Operations Office

785 DOE Place

Idaho Falls, ID 83402

Project Manager: P.A. Brookshier

Telephone: 583-1403 (FTS)

(208) 526-1403 (Com)

Contractor:

Idaho National Engineering Laboratory

EG\&G Idaho, Inc.

P.O. Box 1625

Idaho Falls, ID 83415

Principal Investigator: J. Renner

Telephone: 583-9824 (FTS)

(208) 526-9824 (Com)

Contract Number: AC07-76ID01570

Contract Period: 10/27/87 - Open

Contract Funding (Source):

FY 1989: $\$ 270,000$ (DOE)

\section{Objectives:}

To increase the success ratio of in-fill wells for production and injection, i.e., decrease the dry-hole ratio for in-fill wells for production and injection by $33 \%$ by 1992 ; to improve methods for positioning and designing geothermal production and injection wells to reduce the aggregate cost of wells by $15 \%$ by 1992 ; and to reduce uncertainties related to long-term reservoir changes in fluid temperature and injection breakthrough by $10 \%$ by 1992 .

\section{Approach/Background:}

To predict the effect of injection on production, develop capability to model behavior of pressure, chemical, and thermal fronts resulting from injected fluids. Identify transport mechanisms governing flow of tracers through fractures.

\section{Status/Accomplishments:}

Completed interim version of the code, FRACUNIX. The code was presented to industry at a two-day workshop in early 1989.

Major Project Reports:

Miller, J.D., et al., FRAC-UNIX Users Manual.

Summary Date: October 1989 


\section{Cooperative Research}

Project/Task:

Reservoir Technology/Geothermal Technology

Organization

Directing Organization:

Idaho Operations Office

785 DOE Place

Idaho Falls, ID 83402

Project Manager: P.A. Brookshier

Telephone: 583-1403 (FTS)

(208) 526-1403 (Com)

Contractor:

Idaho National Engineering Laboratory

EG\&G Idaho, Inc.

P.O. Box 1625

Idaho Falls, ID 83415

Principal Investigator: J. Renner

Telephone: 583-9824 (FTS) (208) 526-9824 (Com)

Contract Number: AC07-76ID01570

Contract Period: 10/25/87 - Open

Contract Funding (Source):

FY 1989: $\$ 100,000$ (DOE)

Objective:

To respond to industry priorities in exploiting the commercial potential of research technology.

Approach/Background:

Sponsor cooperative development with the geothermal industry of technology with a high likelihood of yielding near-term benefits to the industry. Research is conducted under the aegis of the Geothermal Technology Organization; industry funds at least $51 \%$ of all projects.

\section{Status/Accomplishments:}

Joint investigations were completed at The Geysers between DOE and the Geothermal Technology Organization. Cost-shared research recorded data from an advanced seismic array at the site using sophisticated seismic techniques for monitoring the effects of injection near a well at The Geysers field.
Additional cost-shared seismic studies are contemplated at another field during 1990.

Major Project Reports: None

Summary Date: October 1989 


\section{Scientific Drilling}

Project/Task:

Reservoir Technology/Salton Sea Scientific Drilling

Directing Organization:

San Francisco Operations Office

1333 Broadway

Oakland, CA 94612

Project Manager: E. Romo

Telephone: 536-6403 (FTS)

(415) 273-6403 (Com)

Contractor:

Bechtel National, Inc.

P.O. Box 3965

San Francisco, CA 94119

Principal Investigator: C. Snyder

Telephone: (415) 768-5622 (Com)

Contract Number: AC03-84-SF12194

Contract Period: 09/10/84 - 03/31/89

Contract Funding (Source):

FY 1989: $\$ 480,000$ (DOE)

\section{Objectives:}

To investigate a hydrothermal system at depths greater than has been possible previously to better understand the genesis and structure of hydrothermal systems and to assess theories that the nation's hydrothermal resources are far larger than previously estimated.

\section{Approach/Background:}

Better define the Salton Sea hydrothermal system, test for extension of the system to greater depths, and obtain unique scientific data.

\section{Status/Accomplishments:}

The testing facilities were decommissioned, and the site was retumed to the industrial leaseholder. During the course of site cleanup, more than 1800 tons of sludge that had accumulated in the brine holding pond during previous tests of the deep well were processed and removed to a licensed disposal facility. A draft final report for the entire project was prepared. Plans were in process to conduct a two-day, scientific workshop on the project's findings. Final report in preparation to be published in spring 1990.

Major Project Reports: None

Summary Date: October 1989 


\section{Lost-Circulation Control}

Project/Task:

Hard Rock Penetration/Lost-Circulation Control

Directing Organization:

Albuquerque Operations Office

P.O. Box 5400

Albuquerque, NM 87115

Project Manager: G.P. Tennyson

Telephone: (505) 846-3219 (Com)

Contractor:

Sandia National Laboratories

P.O. Box 5800

Albuquerque, NM 87185

Principal Investigator: D.A. Glowka

Telephone: (505) 844-3601 (Com)

Contract Number: 0728.000

Contract Period: 10/17/83 - Open

Contract Funding (Source):

FY 1989: \$525,000 (DOE)

\section{Objective:}

To reduce costs associated with lost-circulation episodes by $30 \%$ by 1992 .

\section{Approach/Background:}

The loss of drilling fluid circulation has been identified by industry as the single most-expensive issue in geothermal drilling because of the time and expense incurred in recovering circulation and the potential for causing more severe problems such as borehole instability, stuck drill strings, and poor casing cement jobs. New technology is being developed to reduce the costs of lost-circulationrelated problems by helping to identify the location and magnitude of loss zones and providing new materials and techniques for plugging them.

\section{Status/Accomplishments:}

Designed and fabricated a high-differential pressure cement tester for evaluating cementitious muds employing an encapsulated accelerator for lost circulation control. Successfully tested the laboratory system and delivered it to Brookhaven
National Laboratory for use in cement formulation studies. Also, developed flow models for cementitious muds in planar and radial fractures as a first step in understanding the dynamics of lost circulation setting fluids under downhole conditions.

Developed a concept and filed a patent application for a system to inject a cementitious mud accelerator and bridging particles downhole as an alternative to the accelerator encapsulation concept for lost circulation control. Completed an analysis of the polyurethane foam failure in The Geysers field test. Concluded that mixing of the foam chemicals with the ambient water is responsible for poor foam expansion under elevated pressures. Filed a patent application for a porous packer concept that may prevent excessive mixing downhole and allow the foam concept to work.

Finally, completed testing of a composite groundrubber-tire/walnut-shell lost-circulation material capable of forming plugs inside fractures rather than at the wellbore wall. Successfully utilized groundrubber-tire lost-circulation material in drilling DOE's magma well.

\section{Major Project Reports:}

Loeppke, G.E., D.A. Glowka, and E.K. Wright, Design and Evaluation of Lost Circulation Materials for Severe Environments.

Summary Date: October 1989 


\section{Rock Penetration Mechanics}

Project/Task:

Hard Rock Penetration/Rock Penetration Mechanics

Directing Organization:

Albuquerque Operations Office

P.O. Box 5400

Albuquerque, NM 87115

Project Manager: G.P. Tennyson

Telephone: (505) 846-3219 (Com)

Contractor:

Sandia National Laboratories

P.O. Box 5800

Albuquerque, NM 87185

Principal Investigator: J.T. Finger

Telephone: (505) 844-8089 (Com)

Contract Number: 0728.000

Contract Period: 10/17/83 - Open

Contract Funding (Source):

FY 1989: \$575,000 (DOE)

\section{Objective:}

To reduce costs of deep wells and directionally drilled wells by $10 \%$ by 1992 .

\section{Approach/Background:}

Geothermal drilling technology is largely derived from the oil and gas industry but requires advancements due to geothermal's high temperatures, hard-abrasive rock, underpressured formations, highly fractured zones, and the presence of highly corrosive fluids. Since oil and gas wells outnumber geothermal wells drilled annually by a factor of about 1000 to 1 , little economic incentive exists for technology development for the geothermal market by industry.

\section{Status/Accomplishments:}

In acoustical data telemetry, successfully developed analysis capability for drill-string transducers and compared predictions with experiment. Fabricated and successfully demonstrated digital control circuits for drill-string transmitting transducers. Designed and fabricated full-scale drill-string transducers. Telemetry by acoustical carrier waves within the drill string can improve data transmission rates by 50-fold over commercial mud-pulse telemetry.

Designed and placed contracts for four pieces of insulated drill pipe with insulated tool joints to accommodate high-temperature drilling above $300^{\circ} \mathrm{C}$.

Reviewed advanced concepts for drilling or coring in hard rock, and analyzed PDC bits for higher speed applications. Additional work was directed at collecting drilling performance data at the bit face in real time during drilling. This information can be used to optimize drilling parameters and can lead to improved understanding of the reservoir.

Major Project Reports:

Drumheller, D.S., "Acoustical Properties of Drill Strings."

Summary Date: October 1989 


\section{Instrumentation}

Project/Task:

Hard Rock Penetration/Instrumentation

Directing Organization:

Albuquerque Operations Office

P.O. Box 5400

Albuquerque, NM 87115

Project Manager: G.P. Tennyson

Telephone: (505) 846-3219 (Com)

Contractor:

Sandia National Laboratories

P.O. Box 5800

Albuquerque, NM 87185

Principal Investigator: H.T. Chang

Telephone: (505) 844-7588 (Com)

Contract Number: 0728.000

Contract Period: 10/17/83 - Open

Contract Funding (Source):

FY 1989: $\$ 475,000$ (DOE)

Objectives:

To improve well-siting accuracy through better identification of fractures by 1992 and to decrease cost of drilling production-related geothermal wells by about $5 \%$ by 1992 , through more accurate completion-zone siting.

\section{Approach/Background:}

The research and development effort in instrumentation includes developing a radar fracture mapping tool to locate fracture zones in geothermal reservoirs. Most geothermal reservoirs are fracturedominated, and frequently wells drilled as close to a commercial producer as $100 \mathrm{~m}$ have failed to encounter fractures for commercial production. Once fracture zones are located near a noncommercial well, directional drilling can be used to intersect new fractures and improve production. A downhole directional radar tool operating in the frequency range of 30 to $100 \mathrm{MHz}$ is being developed for detection and resolution of producing fractures.
Status/Accomplishments:

Completed final report describing first prototype Borehole Directional Radar. Completed an extensive redesign of the radar tool to improve field operational characteristics and initiated new hardware fabrication. In addition, cost-shared new generation radar tool development with Nuclear Treaty Verification Project. Successfully demonstrated that downhole memory tools can provide high-resolution temperature logs with quality similar to our precision RTD wire line system.

Major Project Reports:

Chang, H.T., Borehole Directional Radar System for Subsurface Scanning.

Chang, H.T., Prototype Borehole Directional Radar System.

Duda, L.E., J.E. Uhl, J. Gabaldon, and H.T. Chang, Detection of a Target in a Rock Formation Using the Radar Fracture Mapping Tool.

Summary Date: October 1989 


\section{Geothermal Drilling Organization}

Project/Task:

Hard Rock Penetration/Geothermal Drilling

Organization

Directing Organization:

Albuquerque Operations Office

P.O. Box 5400

Albuquerque, NM 87115

Project Manager: G.P. Tennyson

Telephone: (505) 846-3219 (Com)

Contractor:

Sandia National Laboratories

P.O. Box 5800

Albuquerque, NM 87185

Principal Investigator: J.C. Dunn

Telephone: (505) 844-4715 (Com)

Contract Number: 0728.000

Contract Period: 10/17/83 - Open

Contract Funding (Source):

FY 1989: $\$ 300,000$ (DOE)

\section{Objectives:}

To develop and to transfer drilling technology to effect a 5\% reduction in well costs by 1992 .

\section{Approach/Background}

The development efforts of the Geothermal Drilling Organization include projects selected by industry for short-term payoff. Current development includes a high-temperaure acoustic borehole televiewer for fracture identification in open holes and for casing inspection in cased wells; a pneumatic turbine for directional drilling; high-temperature drill pipe protectors for drilling in high-temperature, corrosive environments; and high-temperature rotary head seals for geothermal drilling.

\section{Status/Accomplishments:}

Completed surface data acquisition system for the high-temperature borehole televiewer that digitizes, displays, and stores data in real time during logging operations. Successfully tested complete televiewer system in Unocal wells in the Salton Sea at temperatures up to $293^{\circ} \mathrm{C}$. A commercial logging company is being sought to adopt the technology and offer it as a service to the geothermal operators. Completed the fourth field test of the downhole pneumatic turbine in The Geysers. This field test led to extensive redesign of the turbine and gear reduction assembly. Finalized an agreement for commercialization of the pneumatic turbine. (Agreement reached between Rift Engineering and Baker-Hughes.)

New drill pipe protectors were developed and manufactured using a high-temperature elastomer and were successfully tested during drilling in The Geysers. High-temperature elastomers for rotary head seal applications have been evaluated in laboratory testing. A large test facility to repeatedly test head seals under pipe-tripping operations has been built. This facility will be used for elevatedtemperature testing in the laboratory and then used in two field locations where geothermal brine and steam from a wellhead will be circulated through the test fixture.

Major Project Reports: None

Summary Date: October 1989 


\section{Heat Cycle Research Facility Testing}

Project/Task:

Conversion Technology/Heat Cycle Research

Directing Organization:

Idaho Operations Office

785 DOE Place

Idaho Falls, ID 83402

Project Manager: K. Taylor

Telephone: 583-9063 (FTS) (208) 526-9063 (Com)

Contractor:

Idaho National Engineering Laboratory

EG\& $G$ Idaho Inc.

P.O. Box 1625

Idaho Falls, ID 83415

Principal Investigator: G.L. Mines

Telephone: (208) 526-0260 (Com)

Contract Number: 7AC111

Contract Period: 07/17/78 - 09/30/92

Contract Funding (Source):

FY 1989: $\$ 535,000$ (DOE)

\section{Objective:}

To increase net geothermal fluid effectiveness of binary plants by $20 \%$ by 1992 .

Approach/Background:

Characterize the performance of counterflow, intube condensers at various attitudes and operating conditions. Develop high-performance binary cycles for moderate-temperature or high-salinity resources that are beyond the current state of the art and would result in geothermal fluid effectiveness increases as high as $20 \%$ compared to state-of-theart plants. Characterize performance of cycles using working fluids with improved characteristics such as isobutane-hexane or propane-isopentane mixtures.

\section{Status/Accomplishments:}

The preparation of the site adjacent to the $\mathrm{BC}$ McCabe power plant in California's Imperial Valley was completed and the Heat Cycle Research Facility (HCRF) was moved onto the location. After completing tie-ins to fluids supplied from the McCabe plant, the HCRF operation resumed with the isobutane working fluids. The analytical evaluation of the data generated during supercritical cycle testing at the HCRF and current state-of-thetechnology design methods continued. A flaw was noted in the condenser design code which has delayed the reporting of the investigations of condenser performance at the first nonvertical orientation. A site was solicited for investigating the fouling resistance of the polymer-concrete-lined heat exchanger tube. The proposal submitted by the University of Hawaii for conducting the investigations at the Puna Research Center on the island of Hawaii was selected. The design of the installation of the fouling test unit (fabricated during FY 1988) was completed and much of the equipment was prefabricated at the HCRF. The test unit will be moved to the site, and testing will be initiated pending the university's receiving permission to begin the investigations at the Puna site.

\section{Major Project Reports:}

Bliem, C.J., "Advanced Binary Geothermal Power Cycles."

Bliem, C.J., and B.L. Mines, "Advanced Binary Power Plants: Working Fluid Property Determination and Heat Exchanger Design."

Summary Date: October 1989 


\section{Systems Analysis}

Project/Task:

Conversion Technology/Heat Cycle Research

Directing Organization:

Idaho Operations Office

785 DOE Place

Idaho Falls, ID 83402

Project Manager: K. Taylor

Telephone: 583-9063 (FTS) (208) 526-9063 (Com)

Contractor:

Idaho National Engineering Laboratory

EG\&G Idaho, Inc.

P.O. Box 1625

Idaho Falls, ID 83415

Principal Investigator: G.L. Mines

Telephone: (208) 526-0260 (Com)

Contract Number: 7AC111

Contract Period: 07/17/78 - 09/30/92

Contract Funding (Source):

FY 1989: $\$ 140,000$ (DOE)

Objective:

To increase net geothermal fluid effectiveness of binary plants by $20 \%$ by 1992 .

Approach/Background:

Analyze the theoretical and empirical performance of the various heat cycles and components under investigation.

Status/Accomplishments:

Studies were conducted on the potential application of the Kalina cycle in geothermal binary cycles. The results of these studies were published early in FY 1989.

Major Project Reports:

Bliem, CJ., "Advanced Binary Geothermal Power Cycles."

Bliem, CJ., Aspects of the Kalina Technology Applied to Geothermal Power Production.
Bliem, CJ., The Kalina Cycle and Similar Cycles for Geothermal Power Production.

Summary Date: October 1989 


\section{Metastable Supersaturated Expansions}

\author{
Project/Task: \\ Conversion Technology/Heat Cycle Research \\ Directing Organization: \\ Idaho Operations Office \\ 785 DOE Place \\ Idaho Falls, ID 83402
}

Project Manager: K. Taylor

Telephone: 583-9063 (FTS)

(208) 526-9063 (Com)

Contractor:

Idaho National Engineering Laboratory

EG\&G Idaho, Inc.

P.O. Box 1625

Idaho Falls, ID 83415

Principal Investigator: G.L. Mines

Telephone: (208) 526-0260 (Com)

Contract Number: 7AC111

Contract Period: 07/17/78 - 09/30/92

Contract Funding (Source):

FY 1989: $\$ 120,000$ (DOE)

\section{Objective:}

To increase net geothermal fluid effectiveness of conventional binary plants an additional $8 \%$ by 1992 through the utilization of supersaturated vapor turbine expansions.

\section{Approach/Background:}

Determine effect of supersaturated vapor expansions on turbine performance and integrity to establish the feasibility of supersaturated turbine expansions that could increase net fluid effectiveness of conventional powerplants by $8 \%$.

\section{Status/Accomplishments:}

In conjunction with the Heat Cycle Research Facility (HCRF) experiments, North Carolina A\&T State University completed the development of a Laser Droplet Ilumination System to be used at the HCRF as part of the investigation of the condensation behavior of the supersaturated turbine expansions. This system will be used to determine whether condensate droplets form during the turbine expansions passing through the two-phase region. If future investigations show that these types of expansions can operate without condensate forming, it may be possible to achieve a projected additional 8\% performance improvement. The Laser Droplet Illumination System was sent to the HCRF for installation early in FY 1990. An expansion nozzle for simulating the turbine expansions of interest will be delivered to the HCRF late in FY 1989 for installation with the laser system. Once installed, the nozzle and laser will be utilized to detect the presence of condensate. A specification for a radial inflow reaction turbine was prepared; an order will be placed early in FY 1990. This unit will be used to investigate the effect of the supersaturated expansions on turbine performance as well as the higher efficiencies quoted for this type of expander.

\section{Major Project Reports:}

Hingorani, S.K., Laser Based Particle Sizing Technique for Investigation of Condensation Behavior of Hydrocarbons in Flow.

Summary Date: October 1989 


\section{Advanced Heat-Rejection System}

Project/Task:

Conversion Technology/Heat Cycle Research

Directing Organization:

Idaho Operations Office

785 DOE Place

Idaho Falls, ID 83402

Project Manager: K. Taylor

Telephone: 583-9063 (FTS) (208) 526-9063 (Com)

Contractor:

Idaho National Engineering Laboratory

EG\&G Idaho, Inc.

P.O. Box 1625

Idaho Falls, ID 83415

Principal Investigator: G.L. Mines

Telephone: (208) 526-0260 (Com)

Contract Number: 7AC111

Contract Period: 07/17/78 - 09/30/92

Contract Funding (Source):

FY 1989: $\$ 25,000$ (DOE)

\section{Objective:}

To reduce heat rejection system cooling water requirements for geothermal power plants by $20 \%$ by 1991 .

\section{Approach/Background:}

Refine and test heat-rejection schemes that require less cooling water makeup without significant performance penalties in order to expand the useful geothermal resource base, especially at remote desert sites.

Status/Accomplishments:

The scope of work in this area was reduced during FY 1989 due to the Heat Cycle Research Facility relocation activities. Initial scoping studies were initiated in late FY 1989 and will continue during FY 1990.

\section{Major Project Reports:}

Bliem, C.J., and B.L. Mines, "Simple Strategies for Minimization of Cooling Water Usage in Binary Power Plants."

Summary Date: October 1989 


\section{Advanced High-Temperature Cements}

Project/Task:

Conversion Technology/Materials Research

Directing Organization:

Idaho Operations Office

785 DOE Place

Idaho Falls, ID 83402

Project Manager: K. Taylor

Telephone: 583-9063 (FTS) (208) 526-9063 (Com)

Contractor:

Associated Universities, Inc.

Brookhaven National Laboratory

Upton, NY 11973

Principal Investigator: L.E. Kukacka

Telephone: 666-3065 (FTS)

(516) 282-3065 (Com)

Contract Number: AS-17-PSD

Contract Period: 04/01/88 - Open

Contract Funding (Source):

FY 1989: $\$ 375,000$ (DOE)

Objective:

To develop well cementing materials with a service lifetime of 30 years at $400^{\circ}$ to $600^{\circ} \mathrm{C}\left(750^{\circ}\right.$ to $\left.1140^{\circ} \mathrm{F}\right)$ by 1991 .

\section{Approach/Background:}

Improve the effectiveness of geothermal well completion procedures by the development of carbon-dioxide-resistant, high-temperature cements with twice the lifetime of existing cements. These improvements will help to transfer well-life limitations from materials to reservoir constraints in a cost-effective manner.

\section{Status/Accomplishments:}

This effort contains three phases. The first phase, a one-year downhole exposure test of lightweight cements in low- $\mathrm{CO}_{2}$ brines at $300^{\circ} \mathrm{C}\left(572^{\circ} \mathrm{F}\right)$ and the downhole characterization of the performance of these cements, was completed. The second phase involves the development of cements and/or ceramiclike materials for well completions in temperatures up to $500^{\circ} \mathrm{C}\left(930^{\circ} \mathrm{F}\right)$. The pumpability of several of these materials was verified. The third phase is laboratory work to develop advanced hightemperature, $\mathrm{CO}_{2}$-resistant geothermal cements for magma well completion. Initial components identified include a series of high-alumina cements. Tests are continuing.

\section{Major Project Reports:}

Sugama, T., L.E. Kukacka, and N. Carciello, Aluminum Alkoxide Incorporated Calcium Aluminum Cements.

Sugama, T., et al., Interfacial Reactions between Oxidized Carbon Fibers and Cements.

Summary Date: October 1989 


\section{Nonmetallic Heat-Exchanger Tubing}

Project/Task:

Conversion Technology/Materials Research

Directing Organization:

Idaho Operations Office

785 DOE Place

Idaho Falls, ID 83402

Project Manager: K. Taylor

Telephone: 583-9063 (FTS)

(208) 526-9063 (Com)

Contractor:

Associated Universities, Inc.

Brookhaven National Laboratory

Upton, NY 11973

Principal Investigator: L.E. Kukacka

Telephone: (516) 282-3065 (Com)

Contract Number: AS-17-PSD

Contract Period: 10/01/87 - Open

Contract Funding (Source):

FY 1989: $\$ 60,000$ (DOE)

\section{Objective:}

To develop by 1991 a corrosion-resistant and lowfouling heat exchanger material for lining tubes that costs no more than one-third the cost of high-alloy tubes.

\section{Approach/Background:}

Improve the net geothermal fluid effectiveness of binary plants by developing high-thermalconductivity, corrosion-resistant, nonmetallic liners on carbon steel substrates that can be used as a substitute for expensive high-alloy tubes.

\section{Status/Accomplishments:}

Initial preparations were made for a field test of a small prototype shell-and-tube heat exchanger containing thermally conductive polymer-concretelined tubes. Tubes were fabricated at Brookhaven National Laboratory and supplied to Idaho National Engineering Laboratory, where they were assembled into tube bundles and installed in a test apparatus.
Major Project Reports: None

Summary Date: October 1989 


\section{Chemical Systems for Lost-Circulation Control}

\section{Project/Task:}

Conversion Technology/Materials Research

Directing Organization:

Idaho Operations Office

785 DOE Place

Idaho Falls, ID 83402

Project Manager: K. Taylor

Telephone: (208) 526-9063 (Com)

Contractor:

Associated Universities, Inc.

Brookhaven National Laboratory

Upton, NY 11973

Principal Investigator: L.E. Kukacka

Telephone: (516) 282-3065 (Com)

Contract Number: AS-17-PSD

Contract Period: 02/01/88 - Open

Contract Funding (Source):

FY 1989: $\quad \$ 60,000$ (DOE)

Objective:

To reduce costs associated with lost circulation episodes by $30 \%$ by 1992 .

Approach/Background:

To improve the effectiveness of procedures used to control lost circulation problems during well drilling and completion, develop lost-circulation-control materials that enhance the durability of sealing to $\mathbf{3 0}$ days. Develop high-temperature chemical systems that can be introduced through the drill pipe to avoid downtime incurred in removing drill string.

Status/Accomplishments:

Resumed work in developing advanced hightemperature chemical systems for lost-circulation control. Emphasis was placed on a bentonammonium polyphosphate-borax-magnesium oxide $(\mathrm{MgO})$ system. Methods for the microencapsulation of the $\mathrm{MgO}$ in epoxies and other polymers were investigated over the temperature range of $150^{\circ}$ to $350^{\circ} \mathrm{C}$.

\section{Major Project Reports:}

Sugama, T., L.E. Kukacka, B.G. Galen, and N.B. Milestone, "Characteristics of HighTemperature Cementitious Lost-Circulation Control Materials for Geothermal Wells."

Summary Date: October 1989 


\section{Modeling of Complex Brines}

Project/Task:

Conversion Technology/Advanced Brine Chemistry

Directing Organization:

Idaho Operations Office

785 DOE Place

Idaho Falls, ID 83402

Project Manager: I. Aoki

Telephone: 583-0583 (FTS)

(202) 526-0583 (Com)

Contractor:

University of California at San Diego

La Jolla, CA 92093-0340

Principal Investigator: J. Weare

Telephone: (619) 534-3286 (Com)

Contract Number: DE-AC03-88-SF17712

Contract Period: 01/01/88 - 09/30/90

Contract Funding (Source):

FY 1989: $\$ 125,000$ (DOE)

\section{Objectives:}

To reduce geothermal-production-well maintenance costs related to scale deposition by $20 \%$ by 1992 ; to reduce geothermal field surface equipment costs related to scale deposition by $20 \%$ by 1992 ; and to reduce geothermal powerplant maintenance and equipment replacement costs related to scale deposition by $20 \%$ by 1992 .

\section{Approach/Background:}

Prepare a dynamic model of brine chemistry thermal equilibria and kinetics that synthesizes the observed behavior of major ionic species at temperatures as high as $250^{\circ} \mathrm{C}\left(482^{\circ} \mathrm{F}\right)$ and enables reliable estimates of scaling potential.

\section{Status/Accomplishments:}

Initiated research including modeling of sulfate aqueous species into the dynamic model of brine chemistry and improved the model's capabilities in understanding ion interactions.

\section{Major Project Reports:}

Weare, J., "Prediction of Scaling in Geothermal Systems."

Summary Date: October 1989 


\section{Biochemical Processes}

Project/Task:

Conversion Technology/Advanced Brine Chemistry

\section{Directing Organization:}

Brookhaven Area Office

Brookhaven National Laboratory

Upton, NY 11973

Project Manager: J. Bellows

Telephone: 666-3424 (FTS)

(516) 282-3424 (Com)

Contractor:

Associated Universities, Inc.

Brookhaven National Laboratory

Upton, NY 11973

Principal Investigator: E.T. Premuzic

Telephone: 666-2893 (FTS)

(516) 282-2893 (Com)

Contract Number: ACO2-76CH00016

Contract Period: 07/01/85 - Open

Contract Funding (Source):

FY 1989: \$200,000 (DOE)

\section{Objective:}

To reduce costs of surface disposal of sludge from geothermal brines by 25\% or more by 1995 .

\section{Approach/Background:}

Develop economic and environmentally acceptable methods for disposal of geothermal wastes. Toxic elements found in geothermal residues are solubilized and/or concentrated using microorganisms, so the remaining brine can be reinjected and the metals easily removed.

\section{Status/Accomplishments:}

Completed scaleup of three types of working fluid bioreactors: flat bed, column, and fluidized bed. Initiated additional kinetic studies using results from scaleup bioreactors. Initiated second technical and economic feasibility study using scaled-up results.

\section{Major Project Reports:}

Premuzic, E.T., "Developments in Geothermal Waste Treatment Biotechnology."

Premuzic, E.T., and M.S. Lin, "The Role of Biotechnology in the Treatment of Geothermal Residual Sludges."

Premuzic, E.T., et al., "Regional Variation in the Metal Composition of Residual Brine Sludges Derived from Geothermal Power Plants."

Summary Date: October 1989 

Magma

$53 / 54$ 



\section{Drilling and Engineering}

Project/Task:

Long Valley Operations/Drilling and Engineering

Directing Organization:

Albuquerque Operations Office

P.O. Box 5400

Albuquerque, NM 87115

Project Manager: G.P. Tennyson

Telephone: $846-3219$ (FTS)

(505) 846-3219 (Com)

Contractor:

Sandia National Laboratories

P.O. Box 5800

Albuquerque, NM 87185

Principal Investigator: J.C. Dunn

Telephone: $844-4715$ (FTS)

(505) $844-4715$ (Com)

Contract Number: ACO4-76DP00789

Contract Period: 10/20/83 - Open

Contract Funding (Source):

FY 1989: $\$ 1,700,000^{*}$ (DOE)

*Includes some carryover funds from FY 1988.

Objectives:

To drill and to complete a multistaged exploratory well in Long Valley caldera to depths exceeding 20,000 ft by 1992 .

\section{Approach/Background:}

Drill a deep research well in the southern portion of the caldera in three to five stages. Use the Long Valley well as an exploration tool to confirm the existence of a magma body at shallow depths. Develop and/or test first-generation drilling techniques and materials required to enter a magma body.

Status/Accomplishments:

Obtained approval and permits to drill Long Valley exploratory well to a depth of $20,000 \mathrm{ft}$ in four phases. Selected drilling contractor (Loffland
Brothers) for Phase I drilling. Completed Phase I drilling to a depth of $2568 \mathrm{ft}$.

Major Project Reports:

Finger, J.T., The Magma Energy Program.

Summary Date: October 1989 


\section{Supporting Science}

Project/Task:

Long Valley Operations/Supporting Science

Directing Organization:

Albuquerque Operations Office

P.O. Box 5400

Albuquerque, NM 87115

Project Manager: G.P. Tennyson

Telephone: 846-3219 (FTS)

(505) $846-3219$ (Com)

Contractor:

Sandia National Laboratories

P.O. Box 5800

Albuquerque, NM 87185

Principal Investigator: J.C. Dunn

Telephone: 844-4715 (FTS)

(505) $844-4715$ (Com)

Contract Number: ACO4-76DP00789

Contract Period: 10/20/83 - Open

Contract Funding (Source):

FY 1989: $\$ 100,000$ (DOE)

\section{Objectives:}

To understand the nature of geophysical anomalies at the Long Valley caldera, using actual well observation data, and to verify the depth and lateral extent of a magma body by 1992 .

\section{Approach/Background:}

Drill a deep research well in the southern portion of the caldera in three to five stages. Once the well is beyond $7000 \mathrm{ft}$, make geophysical measurements that will avoid the attenuation and structural complications introduced by caldera fill and provide better quality data. Perform experiments and analyses relevant to the geology and geochemistry of the well's surroundings. Correlate data with abundant surface data.

\section{Status/Accomplishments:}

Signed interagency agreement designating the Long Valley well as a formal Continental Scientific Drilling Project. Published a science guide for scientific measurements in the Long Valley well.
Developed (with Magma Science Panel) a proposal for scientific measurements following Phase I drilling. Completed management plan for coordination of studies by supporting science groups.

Major Project Reports:

Rundle, J.B., Magma Energy Science Guide for Long Valley.

Summary Date: October 1989 


\section{Geochemistry and Materials}

Project/Task:

Laboratory and Engineering Support/Geochemistry and Materials

Directing Organization:

Albuquerque Operations Office

P.O. Box 5400

Albuquerque, NM 87115

Project Manager: G.P. Tennyson

Telephone: 846-3219 (FTS)

(505) 846-3219 (Com)

\section{Contractor:}

Sandia National Laboratories

P.O. Box 5800

Albuquerque, NM 87185

Principal Investigator: T.M. Gerlach

Telephone: 844-5929 (FTS)

(505) $844-5929$ (Com)

Contract Number: ACO4-76DP00789

Contract Period: 10/20/83 - Open

Contract Funding (Source):

FY 1989: \$175,000 (DOE)

\section{Objectives:}

To evaluate performance of materials in the corrosive and volatile rich magma environment for use in drilling tools by 1992 ; by 1995 , to predict rates for dissolution of silicate minerals and the composition of fluid in rock-to-water heat exchanger system and to evaluate the potential for loss of permeability due to precipitation of secondary minerals; and to evaluate magma degassing hazards associated with drilling and energy extraction at Long Valley, California.

\section{Approach/Background:}

Evaluate the performance of materials that will withstand conditions in a magma environment. Carry out research to address development of both a high-temperature weighting material for drilling fluid and a high-temperature casing support material. Also, characterize available commercial metals for possible use in a magma chamber. Analyze and characterize the geochemistry of magma to understand compositional variations and phase relationships.

\section{Status/Accomplishments:}

Published report summarizing our recommendations for materials to be used in magma energy extraction and the problems associated with dissolution and precipitation.

\section{Major Project Reports:}

Casey, W.H., H.R. Westrich, and G.W. Amold, "Surface Chemistry of Labradorite Feldspar Reacted with Aqueous Solutions at pH-2, 3, and 12."

Summary Date: October 1989 


\section{Energy Extraction}

Project/Task:

Laboratory and Engineering Support/Energy

Extraction

Directing Organization:

Albuquerque Operations Office

P.O. Box 5400

Albuquerque, NM 87115

Project Manager: G.P. Tennyson

Telephone: 846-3219 (FTS)

(505) 846-3219 (Com)

Contractor:

Sandia National Laboratories

P.O. Box 5800

Albuquerque, NM 87185

Principal Investigator: T.Y. Chu

Telephone: $844-3953$ (FTS)

(505) 844-3953 (Com)

Contract Number: ACO4-76DP00789

Contract Period: 10/20/83 - Open

Contract Funding (Source):

FY 1989: \$200,000 (DOE)

Objective:

To evaluate methods for energy extraction from a magma body.

\section{Approach/Background:}

The energy extraction rate has a controlling influence on the economic viability of magma energy. An open heat exchanger concept, in which fluid is circulated through the interconnecting fractures in the solidified region around drilling tubing, offers the promise of very high rates of energy production on the order of $30 \mathrm{MWe}$.

To evaluate heat transfer processes, our research is addressing five areas: (1) fundamental mechanisms of solidifying and thermally fracturing magma, (2) convective heat transfer in the internally fractured solidified magma, (3) convective flow in the molten magma and heat transfer from the magma to the cooled heat exchanger, (4) numerical simulation of the overall energy extraction process, and (5) thermodynamics of energy conversion in a magma power plant at the surface.

While the long-term goal of the Magma Energy Program is to demonstrate energy extraction in the megawatt range in a field experiment, current objectives are to achieve a thorough understanding of the physical processes involved in extracting energy from magma using direct contact heat transfer and to demonstrate the direct contact concept in integrated experiments in the kilowatt range. The integrated experiment is a bridge between laboratory experiments and megawatt field experiments.

\section{Status/Accomplishments:}

Published report summarizing our past work in energy extraction, including presenting best estimates for power production from magma.

\section{Major Project Reports:}

Chu, T.Y., and C.E. Hickox, "Thermal Convection with Large Viscosity Variation in an Enclosure with Localized Heating."

Summary Date: October 1989 


\section{Drilling Techniques}

Project/Task:

Laboratory and Engineering Support/Drilling

Techniques

Directing Organization:

Albuquerque Operations Office

P.O. Box 5400

Albuquerque, NM 87115

Project Manager: G.P. Tennyson

Telephone: 846-3919 (FTS)

(505) $846-3219$ (Com)

Contractor:

Sandia National Laboratories

P.O. Box 5800

Albuquerque, NM 87185

Principal Investigator: J.T. Finger

Telephone: $844-8089$ (FTS)

(505) 844-8089 (Com)

Contract Number: AC04-76DP00789

Contract Period: 10/20/83 - Open

Contract Funding (Source):*

(DOE)

\footnotetext{
* No direct funding for this project exists under the Magma category; however, some related work was covered under Hydrothermal Hard Rock Penetration.
}

\section{Objectives:}

By 1992, to design and to develop technology capable of drilling into magma at temperatures at least as high as $900^{\circ} \mathrm{C}\left(1700^{\circ} \mathrm{F}\right)$ and at total depths at least as deep as $5 \mathrm{~km}$.

\section{Approach/Background:}

Design, fabricate, and test drilling equipment or materials for penetrating a magma body that can withstand the higher temperatures, pressures, and volumes of dissolved gases. Investigate creep of viscous rock that could cause the wellbore to squeeze in behind the bit during drilling and reheating of the surrounding rock and creep closure of the well after circulation is lost.
Status/Accomplishments: None

Major Project Reports: None

Summary Date: October 1989 

Current Publications

$61 / 62$ 



\section{Geopressured-Geothermal}

Dunlap, H., 1989, "An Overview of Recent Logging Research at the University of Texas Petroleum Engineering Department," CONF-890352, Proceedings of the DOE Geothermal Program Review VII, San Francisco, CA, March 21-23.

Dunlap, H., Nov.-Dec. 1988, "Boron: Tracking a Trace Element," The Log Analyst, p. 8.

Eaton, B.A., C.R. Featherston, and T. E. Meahl, 1989, "Pleasant Bayou Operations, Brazoria County, Texas," CONF-890352, Proceedings of the DOE Geothermal Program Review VII, San Francisco, CA, March 21-23.

John, C.J., D.A. Stevenson, and C. Groat, 1989, "Geopressured-Geothermal Resources of the Northern Gulf of Mexico Basin-Geology Test Results and Environmental Monitoring," Proceedings of the International Geological Congress, Washington, DC, July 9-19.

Negus-de Wys, J., 1989, "Status of the Hybrid Power System and Future Utilization Possibilities of the Geopressured Resource," Proceedings of the 24th Intersociety Energy Conversion Engineering Conference, Washington, DC, August 7-11.

\section{Hot Dry Rock}

Birdsell, S.A., 1988, "Prediction of Thermal Front Breakthrough Due to Fluid Reinjection in Geothermal Reservoirs," Geothermal Energy Symposium, ASME/GRC, New Orleans, LA.

Brown, D.W., 1988, "Anomalous Earth Stress Measurements During a Six-Year Sequence of Pumping Tests at Fenton Hill, New Mexico," 2nd International Workshop on Hydraulic Fracturing Stress, Minneapolis, MN.

Burns, K.L., 1987, Geological Structures from Televiewer Logs of GT-2. Fenton Hill: Part 1, Feature Extraction; Part 2, Rectification; Part 3, Quality Control, LA-10619-HDR, Los Alamos, NM: Los Alamos National Laboratory.

Dreesen, D.S., et al., 1987, "Developing Hot Dry Rock Reservoirs with Inflatable Open Hole Packers," Geothermal Resources Council Transactions, Vol. 11.

Jermance, R.L., et al., 1987, "Applications of a Downhole Programmable Microprocessor for a Geothermal Borehole Inspection Tool," Geothermal Resources Council Transactions, Vol. 11.
Murphy, H., et al., 1988, "Hot Dry Rock Fracture Propagation and Reservoir Characterization," Proceedings of the DOE Geothermal Program Review VI, San Francisco, CA.

Robinson, B.A., 1988, "Fracture Network Modeling of a Hot Dry Rock Geothermal Reservoir," 13th Annual Workshop on Geothermal Reservoir Engineering, Stanford University, Stanford, CA.

Schillo, J.C., et al., 1988, "Redrilling of Well EE3 at the Los Alamos National Laboratory HDR Project," Geothermal Resources Council Transactions, Vol. 11.

\section{Hydrothermal}

Adams, M.C., and J. Davis, Thermal Decay Kinetics of the Tracer Dye Fluorescein, ESL-89014-TR, DOE/ID/12489-49, Salt Lake City, UT: University of Utah Research Institute, Earth Science Laboratory (in press).

Adams, M.C., W.R. Benoit, C. Doughty, G.S. Bodvarsson, and J.N. Moore, 1989, "The Dixie Valley, Nevada, Tracer Test," presented at the Geothermal Resources Council 1989 Annual Meeting. Also ESL-89036-JP, DOE/ID/12489-69, Salt Lake City, UT: University of Utah Research Institute, Earth Science Laboratory.

Adams, M.C., J.N. Moore, and P.M. Wright, 1989, The Use of Tracers to Analyze the Effects of Reinjection into Fractured Geothermal Reservoirs, ESL-89037-JP, DOE/ID/12489-70, Salt Lake City, UT: University of Utah Research Institute, Earth Science Laboratory.

Allison, M.L., and D.L. Nielson, 1989, Variations of In-Situ Stress in Geothermal Systems of the Basin and Range Province, ESL-89041-JP, DOE/ID/1248973. Salt Lake City, UT: University of Utah Research Institute, Earth Science Laboratory.

Beasley, C.W., 1989, Cross-Borehole Resistivity Inversion-Theory and Application to Monitoring Enhanced Oil Recovery, Ph.D. Thesis, Salt Lake City, UT: University of Utah, Department of Geology and Geophysics. Also ESL-89003-TR, DOE/ID/12489-42, Salt Lake City, UT: University of Utah Research Institute, Earth Science Laboratory.

Beasley, C.W., and S.H. Ward, 1988, "CrossBorehole Resistivity Inversion," Expanded Abstracts of the 58th Annual International Society of Exploration Geophysicists Meeting, Vol. 1, pp. 198200. 
Benson, S.M., J.S. Daggett, J. Ortfz, and I. Iglesias, 1989, "Permeability Enhancement Due to Cold Water Injection: A Case Study at the Los Azufres Geothermal Field, Mexico," Proceedings of the Final Symposium on the DOE/CFE Agreement, San Diego, CA, April 4-5. Also LBL-27350, Berkeley, CA: Lawrence Berkeley Laboratory.

Bliem, CJ., 1989, "Advanced Binary Geothermal Power Cycles," Invited Lecture, presented at Short Course on Geothermal Power Plant Design and Operation, Geothermal Resources Council, Sparks, NV, April.

Bliem, C.J., 1989, Aspects of the Kalina Technology Applied to Geothermal Power Production, EGG-EP8708, Idaho Falls, ID: EG\&G Idaho, Inc.

Bliem, C.J., 1988, The Kalina Cycle and Similar Cycles for Geothermal Pawer Production, EGG-EP8132, Idaho Falls, ID: EG\&G Idaho, Inc.

Bliem, C.J., and G.L. Mines, 1989, "Advanced Binary Power Plants: Working Fluid Property Determination and Heat Exchanger Design," CONF890352, Proceedings of the DOE Geothermal Program Review VII, San Francisco, CA, March 21-23, pp. 89-96.

Bliem, C.J., and G.L. Mines, 1989, "Simple Strategies for Minimization of Cooling Water Usage in Binary Power Plants," Geothermal Resources Council Transactions, Vol. 13.

Bodvarsson, G.S., 1988, "Model Predictions of the Svartsengi Reservoir, Iceland." Water Resources Research, Vol. 24, No. 10, pp. 1740-1746. Also LBL-21253, Berkeley, CA: Lawrence Berkeley Laboratory.

Bodvarsson, G.S., K. Pruess, C. Haukwa, and S.B. Ojiambo, "Evaluation of Reservoir Predictions for the Olkaria Geothermal Field, Kenya," Proceedings of the 14th Workshop on Geothermal Reservoir Engineering, Stanford, CA, January 24-26 (in press). Also to be published in Geothermics. Also LBL26771, Berkeley, CA: Lawrence Berkeley Laboratory.

Bodvarsson, G.S., and V. Stefansson, 1989, "Some Theoretical and Field Aspects of Reinjection in Geothermal Reservoirs," Water Resources Research, Vol. 25, No. 6, pp. 1235-1248.

Chang, H.T., Borehole Directional Radar System for Subsurface Scanning, Albuquerque, NM: Sandia National Laboratories.
Chang, H.T., Prototype Borehole Directional Radar System, Albuquerque, NM: Sandia National Laboratories.

Cox, B.L., and K. Pruess, 1989, "Numerical Experiments on Convective Heat Transfer in Watersaturated Porous Media at Near-Critical Conditions," to be published in Transport in Porous Media. Also LBL-26060, Berkeley, CA: Lawrence Berkeley Laboratory.

Drumheller, D.S., 1989, "Acoustical Properties of Drill Strings," Journal of the Acoustical Society of America, Vol. 85, No. 3.

Duda, L.E., J.E. Uhl, J. Gabaldon, and H.T. Chang, 1988, Detection of a Target in a Rock Formation Using the Radar Fracture Mapping Tool, SAND881582C, Albuquerque, NM: Sandia National Laboratories. Also Geothermal Resources Council 1988 Meeting, San Diego, CA, October 9-12.

Goldstein, N.E., and RJ. Alvarez, 1989, "SelfPotential Anomaly Changes at the Cerro Prieto Geothermal Field," Proceedings of the Final Symposium on the DOE/CFE Agreement, San Diego, CA, April 4-5.

Goldstein, N.E., S.E. Halfman, R.F. Corwin, and R.J. Alvarez, "Self-Potential Anomaly Changes at the East Mesa and Cerro Prieto Geothermal Fields," Proceedings of the 14th Workshop on Geothermal Reservoir Engineering, Stanford, CA, January 2426 (in press).

Halfman-Dooley, S.E., M.J. Lippmann, and G.S. Bodvarsson, 1989, "Progress Report on LBL's Numerical Modeling Studies on Cerro Prieto," Proceedings of the Final Symposium on the DOE/CFE Agreement, San Diego, CA, April 4-5. Also LBL-27159, Berkeley, CA: Lawrence Berkeley Laboratory.

Hingorani, S.K., 1988, Laser Based Particle Sizing Technique for Investigation of Condensation Behavior of Hydrocarbons in Flow. Thesis, Greensboro, NC: North Carolina State A\&T.

Horne, R.N., 1988, "Reinjection into Fractured Geothermal Systems," Proceedings of the International Symposium on Geothermal Energy, Kumamoto and Beppu, Japan, November 10-14.

Jalali, Y., A.K. Belani, and K. Fujiwara, 1989, "An Interporosity Flow Model for Naturally Fractured Reservoirs," SPE 18749, Proceedings, SPE California Regional Meeting, Bakersfield, CA, April 5-7. 
Johns, R.T., and Y. Jalali, 1989, "Comparison of Pressure Transient Response in Intensely and Sparsely Fractured Reservoirs," SPE 18800, Proceedings, SPE California Regional Meeting, Bakersfield, CA, April 5-7.

Kikani, J., 1989, Application of Boundary Element Method to Streamline Generation and Pressure Transient Testing, Ph.D. Dissertation, Stanford, CA: Stanford University.

Kikani, J., and R.N. Horne, 1989, "Application of Boundary Element Method to Reservoir Engineering Problems," to be published in The Journal of Petroleum Science and Engineering.

Kikani, J., and R.N. Horne, 1989, "Modeling Pressure Transient Behavior of Sectionally Heterogeneous Reservoir by the Boundary Element Method, "SPE 19778, Proceedings, 64th Annual SPE Technical Conference and Exhibition, San Antonio, TX, October 8-11.

Kocabas, I., 1989, Analysis of Tracer and Thermal Transients During Reinjection, Ph.D. Dissertation, Stanford, CA: Stanford University.

LaBrecque, D.J., 1989, Theoretical Studies of the Cross-Borehole and Borehole-to-Surface Resistivity Methods, Ph.D. Dissertation, Salt Lake City, UT: University of Utah, Department of Geology and Geophysics. Also ESL-89004-TR, DOE/ID/12489. 43, Salt Lake City, UT: University of Utah Research Institute, Earth Science Laboratory.

LaBrecque, D.J., and S.H. Ward, 1988, "TwoDimensional Inversion of Cross-Borehole Resistivity Data Using Moveable Boundaries," Expanded Abstracts of the 58th Annual International Society of Exploration Geophysicists Meeting, Vol. 1, pp. 194-197.

Lemieux, M.M., J.N. Moore, E.P. Gonzales, G. Izquierdo, and R.E. Huitron, 1989, Chemistry of Los Azufres Reservoir Fluids-Data from Fluid Inclusions, ESL-89018-TR, DOE/ID/12489-53, Salt Lake City, UT: University of Utah Research Institute, Earth Science Laboratory.

Little, T.M., J.B. Hulen, and D.L. Nielson, 1989, "Implications of an Unusual Intracaldera Clastic Deposit for Creation of Fracture Permeability in the Valles Hydrothermal System, New Mexico," presented at the Intemational Association of Volcanology and Chemistry of the Earth's Interior, Santa Fe, NM, June 25-July 1. Also ESL-89011ABS, DOE/ER/13936-3, Salt Lake City, UT: University of Utah Research Institute, Earth Science Laboratory.
Loeppke, G.E., D.A. Glowka, E.K. Wright, 1988, Design and Evaluation of Lost Circulation Materials for Severe Environments, SAND88-1910C, Albuquerque, NM: Sandia National Laboratories. Also 1988 SPE Annual Technical Conference and Exhibition, Houston, TX, October 2-5.

Majer, E.L, 1989, "GTO-DOE/Industry Cost Shared Research; Microseismic Characterization Monitoring in Geothermal Systems," CONF-890352, Proceedings of the DOE Geothermal Program Review VII, San Francisco, CA, March 21-23, pp. 53-57. Also LBL26899, Berkeley, CA: Lawrence Berkeley Laboratory.

McKibbin, R., and K. Pruess, 1989, "Some Effects of Non-Condensible Gas in Geothermal Reservoirs with Steam-Water Counterflow," Geothermics, Vol. 18, No. 3, pp. 367-375.

Miller, J.D., et al., FRAC-UNIX Users Manual, informal report, Idaho National Engineering Laboratory (in preparation for early 1990 release).

Moore, J.N, 1989, "Fluid Inclusions Systematics of the Coso Geothermal System," Proceedings of the 2nd Annual Meeting of the Pan American Conference on Research in Fluid Inclusions (PACROF II). Also ESL-89012-ABS, DOE/ID/ 12489-47, Salt Lake City, UT: University of Utah Research Institute, Earth Science Laboratory.

Moore, J.N., M.C. Adams, and L. Fabray, 1989, Comparative Stucty on the Performance of SilicaBased C18 and Polymer Reversed Phases Used for the Analysis of Carboxylic and Sulfonic Acid Geothermal Tracers, ESL-89013-TR, DOE/ID/ 12489-48, Salt Lake City, UT: University of Utah Research Institute, Earth Science Laboratory.

Moore, J.N., M.C. Adams, B.P. Bishop, and P. Hirtz, A Fluid Flow Model of the Coso Geothermal System-Data from Production Fluid and Fluid Inclusions, ESL-89001-JP, DOE/ID/1248940. Salt Lake City, UT: University of Utah Research Institute, Earth Science Laboratory.

Moore, J.N., M.C. Adams, B.P. Bishop, and P. Hirtz, "Geochemistry of the Coso Geothermal System in California," Proceedings of the 14th Workshop on Geothermal Reservoir Engineering, Stanford University, Stanford, CA (in press).

Moore, J.N., J.B. Hulen, M.M. Lemieux, J.N. Sternfeld, and M.A. Walters, 1989, "Petrographic and Fluid Inclusion Evidence for Past Boiling, Brecciation and Associated Hydrothermal Alteration above the NW Geysers Steam Field, CA," Geothermal Resources Council Transactions, Vol. 11. 
Moore, J.N., DI. Nielson, and P.M. Wright, 1989, Recent Developments in Geology, Geochemistry, and Geophysics Applied to Hydrothermal Reservoir Mapping and Monitoring, ESL-89017-TR, DOE/ID/12489-52, Salt Lake City, UT: University of Utah Research Institute, Earth Science Laboratory.

Pool, K.H., PJ. Raney, and D.W. Shannon, 1987, Calcite Solubility in Simulated Geothermal Brines, PNL-6157, Richland, WA: Pacific Northwest Laboratory.

Premuzic, E.T., 1989, "Developments in Geothermal Waste Treatment Biotechnology," presented at DOE Geothermal Program Review VII, San Francisco, CA, March 21-23.

Premuzic, E.T., and M.S. Lin, 1989, "The Role of Biotechnology in the Treatment of Geothermal Residual Sludges," presented at Metals in the Environment International Conference, Geneva, Switzerland, September.

Premuzic, E.T., et al., 1989, "Regional Variation in the Metal Composition of Residual Brine Sludges Derived from Geothermal Power Plants, "Geothermal Science and Technology.

Pruess, K., 1989, "Experimental and Theoretical Studies of Multiphase Flow in Rough-Walled Rock Fractures," presented at SPE Forum on Naturally Fractured Reservoirs, Crested Butte, CO, July 30August 4.

Pruess, K., 1988, "Modeling of Fluid and Heat Flow in Geothermal Reservoirs," Proceedings of the International Symposium on Geothermal Energy, Kumamoto and Beppu, Japan, November. Also LBL-25710, Berkeley, CA: Lawrence Berkeley Laboratory.

Pruess, K., 1988, "Modeling of Geothermal Systems: Fundamental Processes, Computer Simulation, and Field Applications," Proceedings of the 10th New Zealand Geothermal Workshop, Auckland, New Zealand, November, 1988, pp. 15-21. Also to be published in Geothermics. Also LBL-25135, Berkeley, CA: Lawrence Berkeley Laboratory.

Pruess, K., and Y.W. Tsang, "On Relative Permeability of Rough-Walled Fractures," Proceedings of the 14th Workshop on Geothermal Reservoir Engineering, Stanford, CA, January 2426, 1989 (in press). Also LBL-26509, Berkeley, CA: Lawrence Berkeley Laboratory.

Ross, H.P., et al., 1989, Aeromagnetic Studies, Los Azufres Geothermal Area, Michoacan, ESL-89019TR, DOE/ID/12489-54, Salt Lake City, UT:
University of Utah Research Institute, Earth Science Laboratory.

Stark, K.L., and E.L. Majer, 1989, Seismicity of the Southeastern Geysers, LBL-26679, Berkeley, CA: Lawrence Berkeley Laboratory.

Sugama, T., et al., 1988, Interfacial Reactions between Oxidized Carbon Fibers and Cements, Upton, NY: Upton, NY: Brookhaven National Laboratory.

Sugama, T., L.E. Kukacka, and N. Carciello, 1988, Aluminum Alkoxide Incorporated Calcium Aluminum Cements, Upton, NY: Brookhaven National Laboratory.

Sugama, T., L.E. Kukacka, B.G. Galen, and N.B. Milestone, 1987, "Characteristics of High Temperature Cementitious Lost-Circulation Control Materials for Geothermal Wells," Journal of Materials Science, Vol. 21, No. 1, pp. 63-75.

Tripp, A.C., M.M. Lemieux, P.M. Wright, J.N. Moore, and H.P. Ross, 1988, "Physical and Chemical Rock Property Measurements in Geothermal Exploration and Reservoir Studies," Proceedings of the Technical Review on Advances in Geothermal Reservoir Technology Research in Progress, pp. 65-69. Also LBL-25635, Berkeley, CA: Lawrence Berkeley Laboratory.

Wannamaker, P.E., 1988, "Magnetotellurics in Deep Geothermal Exploration-Applications to the Long Valley Magnetic System," Proceedings of the Technical Review on Advances in Geothermal Reservoir Technology Research in Progress, pp. 59-64. Also LBL-25635, Berkeley, CA: Lawrence Berkeley Laboratory.

Ward, S.H., and R.C. West, 1988, "The Borehole Transient Electromagnetic Response of a ThreeDimensional Fracture Zone in a Conductive HalfSpace," Geophysics, Vol. 53, No. 11, pp. 1469. 1478. Also ESL-88003-JP, Salt Lake City, UT: University of Utah Research Institute, Earth Science Laboratory.

Weare, J., 1989, "Prediction of Scaling in Geothermal Systems," presented at DOE Geothermal Program Review VII, San Francisco, CA, March 2123.

Wright, P.M., E. Lira, and D.R. Ramsey, 1989, Interpretation of Landsat Thematic Mapper Satellite Imagery at Los Azufres Geothermal Field, Michoacan, Mexico, ESL-89021-TR, DOE/ID/1248956. Salt Lake City, UT: University of Utah Research Institute. 
Current Publications

Wright, P.M., S.H. Ward, C.W. Beasley, D.J. LaBrecque, J.A. Stodt, and H.P. Ross, 1988, "Research in Borehole Geophysics," Proceedings of the Technical Review on Advances in Geothermal Reservoir Technology Research in Progress. Also LBL-25635, Berkeley, CA: Lawrence Berkeley Laboratory.

Chou, Q., N.E. Goldstein, and A. Becker, 1988, "Crosshole Electromagnetic Responses of Multiple Thin Conductors," presented at the 58th Annual International Meeting of the Society of Exploration Geophysicists, Anaheim, CA, October 31-November 3. Also LBL-25319A, Berkeley, CA: Lawrence Berkeley Laboratory.

Magma

Casey, W.H., H.R. Westrich, and G.W. Arnold, "Surface Chemistry of Labradorite Feldspar Reacted with Aqueous Solutions at pH-2, 3, and 12," Geochimica, Cosmochimica Alta (in press).
Thu, T.Y., and C.E. Hickox, 1988, "Thermal Convection with Large Viscosity Variation in an Enclosure with Localized Heating," Proceedings of the 1988 Winter Annual Meeting of the American Society of Mechanical Engineers, Vol. 99, pp. 1-8, New York: ASME.

Finger, J.T., 1989, "The Magma Energy Program," SAND89-1877, Albuquerque, NM: Sandia National Laboratories.

Rundle, J.B., 1989, "Magma Energy Science Guide for Long Valley," SAND, Albuquerque, NM: Sandra National Laboratories.

$67 / 68$ 


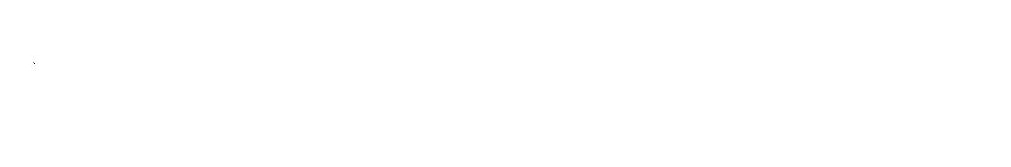




\section{Index of Current Contractors}

Associated Universities, Inc. $\ldots \ldots \ldots \ldots \ldots \ldots \ldots \ldots \ldots \ldots$

$47-49,51$

Bechtel National, Inc.

Brookhaven National Laboratory - See Associated Universities, Inc.

Eaton Operating Company, Inc.

EG\&G Idaho, Inc. - See Idaho National Engineering Laboratory

Idaho National Engineering Laboratory

$36,37,43-46$

Lawrence Berkeley Laboratory

$23,25,28,30,35$

Los Alamos National Laboratory

Louisiana Geological Survey . . . . . . . . . . . . . . . . . . . . . . .

Louisiana State University - See Louisianna Geological Survey

S-Cubed

Sandia National Laboratories

Stanford University

The Ben Holt Co.

University of California at San Diego

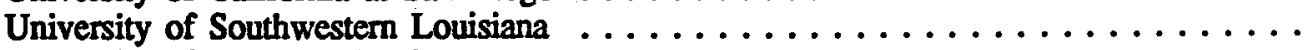

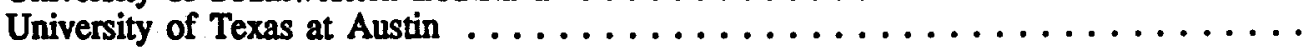

University of Utah Research Institute

$24,26,29,31,33$ 



\title{
Key Contacts
}

Dr. Robert San Martin

Deputy Assistant Secretary,

Renewable Energy

U.S. Department of Energy

(202) 586-9275

Mr. Ronald R. Loose

Director, Office of Renewable

Energy Technologies

U.S. Department of Energy

(202) 586-8084

Dr. John E. Mock

Director, Geothermal

Technology Division

U.S. Department of Energy

(202) $586-5340$

\section{U.S. Department of Energy} Forrestal Building

1000 Independence Ave. S.W. Washington, DC 20585
Mr. George P. Tennyson

Albuquerque Operations Office

U.S. Department of Energy

Management Division

Energy Technologies and

Waste

P.O. Box 5400

Albuquerque, NM 87115

(505) 846-3219

Ms. Peggy Brookshier

Idaho Operations Office

U.S. Department of Energy

785 DOE Place

Idaho Falls, ID 83402

(208) 526-1403

Dr. Richard K. Traeger

Department 6250

Sandia National Laboratories

P.0. Box 5800

Albuquerque, NM 87185

(505) 844-2155
Mr. Robert Hendron

MS J-979

Los Alamos National

Laboratory

P.O. Box 1663

Los Alamos, NM 87545

(505) 665-1418

Dr. Jane Negus-deWys

Idaho National Engineering

Laboratory

EG\&G Idaho, Inc.

1955 Fremont Ave.

Idaho Falls, ID 83415

(208) 526-1744

Dr. Lawrence E. Kukacka

Process Materials Group

Building 526

Brookhaven National

Laboratory

Upton, NY 11973

(516) 282-3065

Dr. Marcelo Lippmann

Earth Sciences Division,

Bldg. 50E

Lawrence Berkeley Laboratory

Berkeley, CA 94720

(415) 486-5035

\section{NOTICE}

This report was prepared as an account of work sponsored by an agency of the United States govemment. Neither the United States government nor any agency thereof, nor any of their cmployees, makes any warranty, express or implied, or assumes any legal liability or responsibility for the accuracy, completeness, or usefulness of any information, apparatus, product, or process disclosed, or represents that its use would not infringe privately owned rights. Reference herein to any opecific commercial product, process, or service by trade name, trademark, manufacturer, or ctherwise does not necessarily constitute or imply its endorsement, recommendation, or favoring by the United States government or any agency thereof. The views and opinions of authors expressed herein do not necessarily state or reflect those of the United States government or any agency thereof.

\author{
Printed in the United States of America \\ Available from: \\ National Technical Information Service \\ U.S. Department of Commerce \\ S285 Port Royal Road \\ Springfield, VA 22161 \\ Price: Microfiche AO1 \\ Printed Copy AOS
}

Codes are used for pricing all publications. The code is determined by the number of pages in the publication. Information pertaining to the pricing codes can be found in the current issue of the following publications which are generally available in most libraries: Energy Research Abstrocts (ERA); Government Reports Announcements and Index (GRA and I); Scientific and Technical Abstract Reports (STAR); and publication NTIS-PR-360 available from NTS at the above address. 